\title{
THRUST BELT ARCHITECTURE OF THE CENTRAL AND SOUTHERN WESTERN FOOTHILLS OF TAIWAN
}

\author{
A Thesis \\ by \\ FERNANDO ANTONIO RODRIGUEZ-ROA \\ Submitted to the Office of Graduate Studies of \\ Texas A\&M University \\ in partial fulfillment of the requirements for the degree of \\ MASTER OF SCIENCE
}

August 2007

Major Subject: Geology 


\title{
THRUST BELT ARCHITECTURE OF THE CENTRAL AND SOUTHERN WESTERN FOOTHILLS OF TAIWAN
}

\author{
A Thesis \\ by \\ FERNANDO ANTONIO RODRIGUEZ-ROA
}

\author{
Submitted to the Office of Graduate Studies of \\ Texas A\&M University \\ in partial fulfillment of the requirements for the degree of \\ MASTER OF SCIENCE
}

Approved by:

Chair of Committee, David V. Wiltschko

Committee Members, John H. Spang Will W. Sager

Head of Department, John H. Spang

August 2007

Major Subject: Geology 


\begin{abstract}
Thrust Belt Architecture of the Central and Southern Western Foothills of Taiwan. (August 2007)

Fernando Antonio Rodríguez-Roa, B.S., Universidad Nacional De Colombia Chair of Advisory Committee: Dr. David Wiltschko
\end{abstract}

A structural model of the central and southern Western Foothills Fold and Thrust Belt (WFFTB) was constructed from serial balanced cross sections. The cross sections are constrained by published surface and subsurface geologic data and thermochronological data. The regional detachment zone is constrained by thrust focal mechanisms to a depth of 10-15 km. Because the current geometries observed within the WFFTB are influenced by the presence of pre-existing normal faults, the WFFTB overall is an inverted basin. Most of the faults of the Western Foothills started their activity before the deposition of the Cholan Fm $(\sim 3.5 \mathrm{Ma})$. There is not a strict forwardbreaking thrust sequence in Taiwan. Out-of-sequence faulting may be due to localized erosion and fault inversion. A new regional structure, the sub-Yuching anticline, is identified in the southern WFFTB. The sub-Yuching anticline is a low ramp angle faultbend-fold with a detachment at $\sim 13 \mathrm{~km}$. The sub-Yuching anticline explains the uplift of the Yuching and Tingpinglin synclines above their regional level and may lie above the continuation of the Manila trench beneath Taiwan.

The estimated aggregate shortening for the easternmost fault of the WFFTB is 
about $40 \mathrm{~km}$ on the central and southern segments. The restored position of the preexisting normal faults places the current trace of the Western Foothills-Slate Belt boundary beneath the Coastal Range. The restoration of WFFTB's rocks to their depositional locations also supports the tectonic model of a crustal-scale thin-skin collisional orogen and rejects a previous hypotheses favoring a deep rooted Central Range. 


\section{ACKNOWLEDGMENTS}

It is a pleasure to thank the many people who made this thesis possible. It is difficult to express my gratitude to my thesis advisor, Dr. David Wiltschko. His constant financial and personal support, his enthusiasm, and his good sense of humor made my time at Texas A\&M a pleasant and constructive experience. His efforts to explain things clearly and simply combined with our constructive discussions helped me clarify lots of concepts and ideas. Throughout my thesis-writing period, he provided sound advice, good teaching, good ideas and showed huge amounts of patience correcting my mistakes (especially with my comas).

I would like to thank my committee members Dr John Spang and Dr Will Sager. The discussions with Dr Spang and his ideas had a big impact in this project. I am especially grateful to my officemates Rafael Almeida and Isaac Perez. They provided their friendship and a fun environment in our office to make me feel like at home. They even laughed with my jokes! Martin Finn, Taka Kanaya and Pablo Cervantes provided the complement for this environment. Thanks to Midland Valley Energy for provide us the academic license of their software 2 DMove ${ }^{\circledR}$ and 3 DMove ${ }^{\circledR}$, special thanks to David Richards. Additional financial support from the M.T. Halbouty scholarship was crucial during hard times, thanks to Mr. Halbouty (R.I.P).

Lastly, and most importantly, I wish to thank my wife Nhora and my daughter Camila for their patience and support during this adventure. I also want to thank my parents who provided me with the education basis to come here and their constant support during my graduate studies. 


\section{TABLE OF CONTENTS}

Page

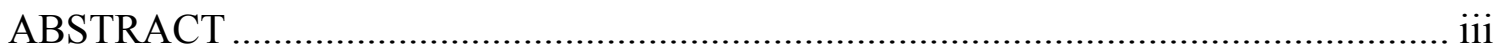

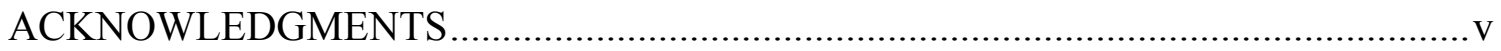

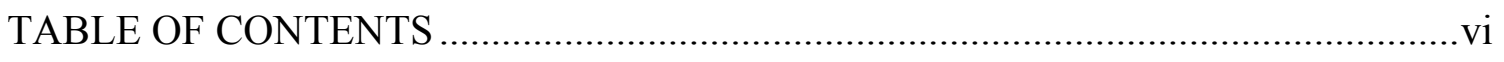

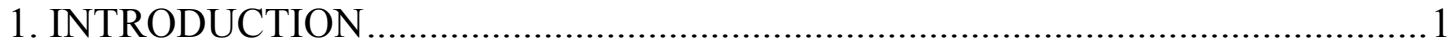

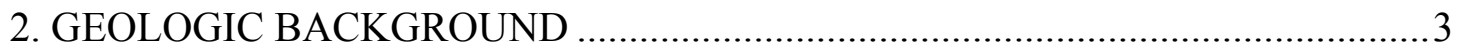

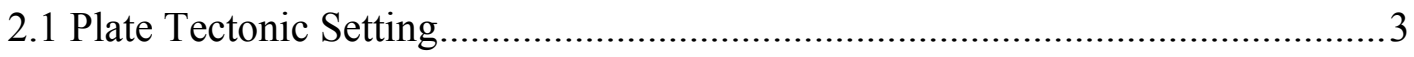

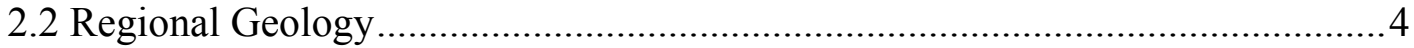

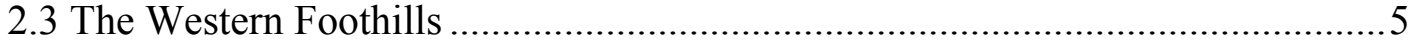

2.3.1 Western Foothills Stratigraphy .......................................................... 6

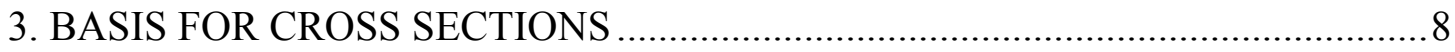

4. DESCRIPTION OF STRUCTURES AND BALANCED CROSS SECTIONS .....12

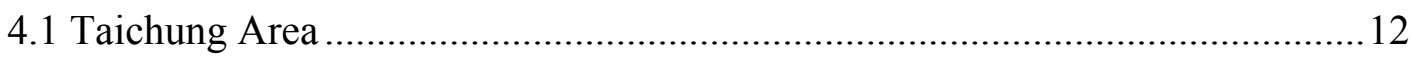

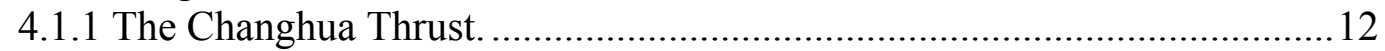

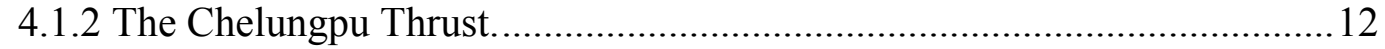

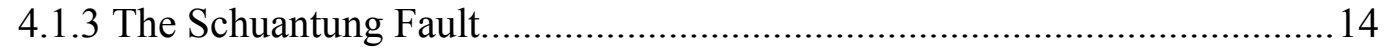

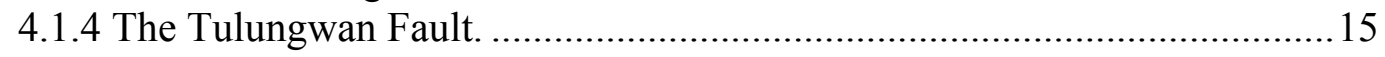

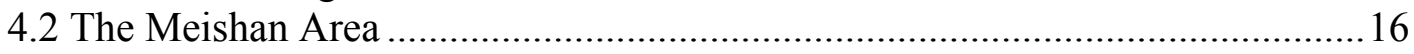

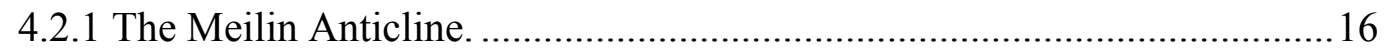

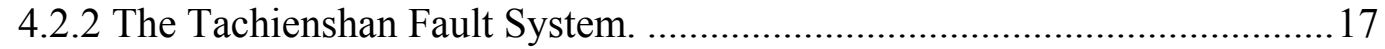

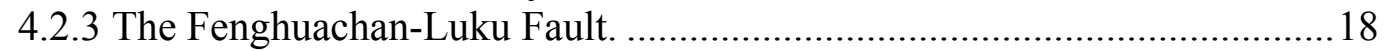

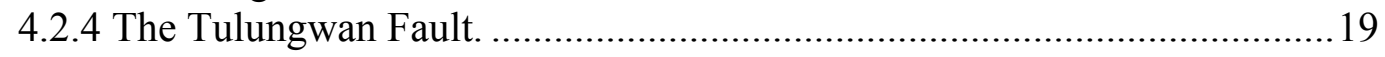

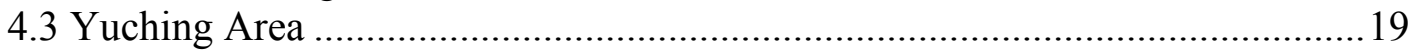

4.3.1 The Chukou and Lunhou Faults........................................................ 19

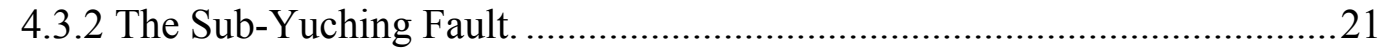

4.3.3 The Pingchi and Chishan Faults.......................................................... 22

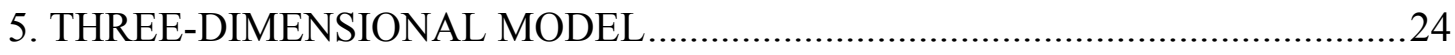

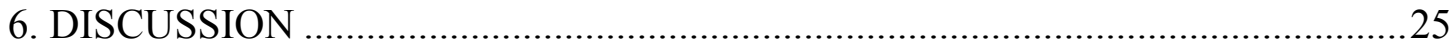

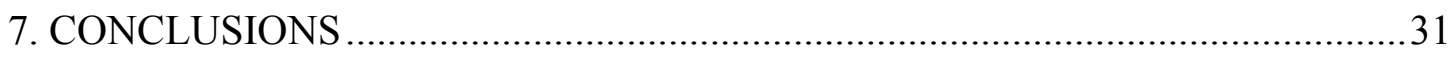




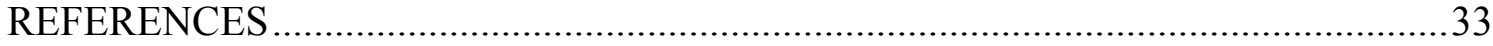

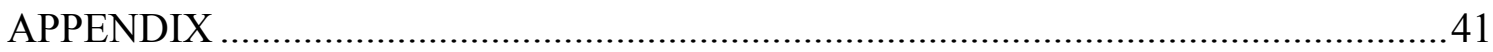

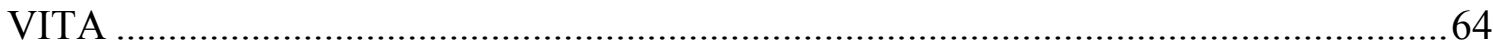




\section{INTRODUCTION}

The Taiwan orogen is a result of the collision between the north-trending Luzon arc and the northeast-trending Eurasian continental margin (Figure 1, all figures referred in text are place in the appendix). Due to the oblique nature of the collision, the site of most intense convergence has propagated southward with time [Suppe, 1984: Lallemand and Tsien, 1997]. The Western Foothills fold and thrust belt represents the deformed foreland basin of the Taiwanese orogen. Due to both its present activity and the availability of geologic and geodetic data this orogen presents an unparalleled opportunity to understand the evolution of a fold and thrust belt.

Three key questions for understanding the structural geology of the Western Foothills are: 1) what is the geometry and kinematics of the main structures in the Western Foothills in three dimensions 2) how was the present day configuration of the Western Foothills influenced by the pre-existing basin architecture and, 3) how do the present motions measured by GPS correspond to the long term motion of the major structures?

To answer these questions we have developed a three-dimensional kinematic model of the central and southern Western Foothills using serial balanced cross sections. These cross sections have been constrained by published subsurface well and seismic reflection, thermochronologic and geodetic data as well as earthquake focal mechanisms.

This thesis follows the style of Tectonics. 
In addition, care has been taken to make the multiple cross sections internally consistent along strike. 


\section{GEOLOGIC BACKGROUND}

\subsection{Plate Tectonic Setting}

The active Taiwan orogen is the result of the oblique collision of the Philippine Sea and the Eurasian plates [e.g. Suppe, 1984; Ho, 1986; Barrier and Angelier, 1986; Tsai, 1986; Teng, 1990; Dadson et al., 2003]. The island of Taiwan lies above both the east dipping Manila and the north dipping Ryukyu subduction zones, respectively (Figure 1). Somewhere beneath Taiwan the subduction polarity flips [e.g., Chiai, 1972; Suppe, 1984; Tsai, 1986; Chemenda et al., 1997; Lallemand et al., 2001]. The Taiwanese orogen is built upon a Paleogene rifted margin. Collision began in the uppermost Miocene and is currently active. Presently the Philippine Sea Plate is moving northwest $\left(306^{\circ}\right)$, toward the $\mathrm{N} 055^{\circ}-070^{\circ}$ trending Eurasian plate margin [Seno et al., 1977; Teng, 1990; Seno et al., 1993; Yu et al., 1997]. The main implication of this oblique collision is that the arc-continent collision has migrated southward through time. Present deformation may be characterized as subduction and accretionary prism growth above the Manila trench to the south of the island of Taiwan, incipient collision in southernmost Taiwan, active collision in the south central portion of the Island, and reduced tectonism in the north [e.g., Teng, 1990; Lallemand and Tsien, 1997].

There are two main hypotheses regarding the timing of the mountain building in Taiwan:

1) The collision has propagated from north to south at rates from 60 to $90 \mathrm{~mm} / \mathrm{yr}$ [Suppe, 1984; Malavieille et al., 2002; Barrier and Angelier, 1986]. Consequently the collision and mountain building processes are older in northern Taiwan than in southern 
Taiwan, the evidence for this is the collision obliquity mentioned above.

2) The onset of the mountain building began at $6 \mathrm{Ma}$ along the length of the orogen [Lee et al., 2006]. From thermochronologic evidence Lee et al. [2006] suggest that the exhumation history of Taiwan may be separated into two stages. The first stage started at $6 \mathrm{Ma}$ and continued until about 1.5 to $1 \mathrm{Ma}$ at a low uplift rate $<1 \mathrm{~mm} / \mathrm{yr}$. A second high uplift rate $(4-16 \mathrm{~mm} / \mathrm{yr})$ stage started at about 1.5 to $1 \mathrm{Ma}$ until the present day [Lee et al., 2006; Lin, 2002]. In the eastern Central Range, the maximum local rates of uplift are 36-42 $\mathrm{mm} / \mathrm{yr}$ during the last decade. These are maximum rates based on leveling measurements [Liu, 1995]. The average rate of uplift now in the Central range is 3-6 mm/yr based on stream erosion rates and thermochronometry [Dadson et al., 2003]. If structural relief were developed in the southern part during the lower Pliocene, it should have controlled the distribution and deposition of Pliocene sedimentary units, consequently affecting both the overburden and the thermal history.

\subsection{Regional Geology}

Taiwan may be divided in five main geological provinces [Ho, 1986, Figure 2]. From west to east, in central and southern Taiwan these are the Coastal Plain, Western Foothills, Slate Belt, Central Range and Coastal Range. The little deformed Coastal Plain province is characterized by both low topographic relief and mainly Quaternary deposits. The western boundary of the Western Foothills is either an emergent or blind thrust at the leading edge of the collision. The Western Foothills overall is a west verging, northeast - southwest trending fold and thrust belt that averages $50 \mathrm{~km}$ wide and more than $380 \mathrm{~km}$ long (Figure 2). This fold and thrust belt contains folded and 
thrusted precollisional continental shelf strata underlying westward prograding synorogenic sediments. The latter clastics were deposited in a rapidly subsiding foreland basin that deepen and accumulated more sediment to the south [Teng, 1990]. Unmetamorphosed Miocene and younger rocks are involved in the Western Foothills structures.

The boundary between the Western Foothills and the Slate Belt to the east is the Tulungwan and Chaochou thrust faults. The exposed Eocene to Oligocene low-grade meta-sediments and underlying rocks of the Slate Belt have been commonly referred as the basement of the Western Foothills. The Slate Belt-Central Range boundary is also marked by thrust and oblique faults. The Central Range, or metamorphic core of the orogen, is composed of pre-Tertiary highly folded and foliated metamorphic rocks including gneisses, schists and some marble. The eastern boundary of the Central Range is the Longitudinal Valley that is considered to be the collapsing forearc basin along the Eurasian/Philippine Sea Plate boundary [Lundberg et al., 1997]. The Coastal Range is a remnant Neogene island arc that is colliding with the Eurasian margin. It is a northern extinct extension of the Luzon magmatic arc.

\subsection{The Western Foothills}

We focus on the fold and thrust belt of the central and southern portion of the Western Foothills. The structures are wide synclines and narrow anticlines above low angle thrust faults. The vergence of the structures is largely westward and the fold axes and fault traces generally trend N10-20E (Figure 3). Some lateral or oblique ramps are sub-perpendicular to the general trend i.e., mainly oriented northwest-southeast (Figure 
3). The Peikang high is a prominent pre-collisional basement high located beneath the Coastal Plain (Figure 2).

Some aspects of any interpretation of the structures at depth are controversial due to incomplete data. Some workers suggest that the Western Foothills fold and thrust belt is a fairly typical forward breaking thin-skin thrust belt [i.e., Suppe, 1984; Dahlen et al., 1989; Hickman et al., 2002]. Other researchers propose that many structures in the Western Foothills both involve pre-Miocene basement and have been inverted [Hung et al., 1999, Mouthereau et al., 2001, Mouthereau et al., 2002, Lee et al., 2002]. The major points of disagreement are: 1) the regional depth to detachment, 2) the role of inversion of pre-existing normal faults, 3) the timing of structures and the presence of out of sequence faulting and, 4) the amount of shortening.

The regional depth to detachment has been placed at several different levels $(\sim 6$ km [Yue et al., 2005]; >9 km [Mouthereau et al., 2002]; 7-12 km [Yang et al., 2007]; $\sim 12$ km [Hickman et al., 2002; Hung et al.,1999; $10 \mathrm{~km}$ Carena et al., 2002]). The main criteria used by previous workers to place these detachments is geometric although Carena et al. [2002] instead used focal mechanisms to place the main detachment zone at $10 \mathrm{~km}$. Based on geometric constructions and focal mechanisms we place that the main detachment zone at a depth between 10-15 km.

The role of fault inversion has been identified [Hung et al., 1999, Mouthereau et al., 2002, Lee et al., 2002], but it has not been fully documented in the foothills area.

\subsubsection{Western Foothills Stratigraphy}

The Eocene to Miocene section begins with rift related to passive margin 
deposits followed by synorogenic clastics since the Upper Miocene. Most of Pliocene and younger sediments are shaly sandstones or sandy shales with alternating sandstones, $[H o, 1988]$. Some of these shales are regional detachment surfaces like the Chinsui shale (Figure 23). The older strata are derived from the Eurasian continent as is indicated by the presence of a continental margin sequence of coastal to shallow-marine siliciclastic sediments derived from Eurasian granitic terrains [Chiai, 1972; Chou, 1973, 1980, Teng, 1990]. The sediment source changed to an easterly source around the middle Pliocene due to uplift of the Central Range [Teng, 1990]. The collision is reflected in the sedimentary record as rapid changes of facies, accelerated basin subsidence, influx of lithic fragments and presence of reworked fossils [Teng, 1990].

An accurate stratigraphic frame for the Western Foothills is difficult to establish. Because the syn-tectonic strata change facies both from north to south and east to west, the stratigraphic nomenclature varies over short distances. In addition, chronostratigraphic control is not of sufficient resolution in key areas. Additionally, the structural complexity of the Western Foothills makes the stratigraphic relationships more complicated. 


\section{BASIS FOR CROSS SECTIONS}

In order to understand the geometry and kinematics of the Western Foothills fold and thrust belt, 13 serial balanced cross sections (Figures 4 to 16) were constructed from the leading edge of the slate belt to the undeformed foreland (Figure 3). These cross

sections were sequentially restored and balanced using $2 \mathrm{DMove}^{\circledR}$. Our procedure was to use kinematic modeling first. If the geometries were too complex we restored them by using line length unfolding and area preservation.

The base geologic maps used are the No. 5- Chia-I, and No.6 Tai-Nan by the Chinese Petroleum Company [CPC, 1986, 1989], and the maps by Chui [1975] and Chang [1971]. We incorporate data from published wells and seismic data [Chang, 1971, Hung et al., 1999, Huang et al., 2004, Yue et al., 2005, Yang et al., 2007] The most important wells incorporated were PKS-1 [Chang, 1971], KTL-3 [Chang et al., 1998], MLN-1, HM-3 [Suppe and Namson, 1979], TSK-1 [Chiu, 1975] (Figure 3)

To tackle the stratigraphic nomenclature problem, a lithostratigraphic approach was adopted. Lithologic units are the basis of surface geologic maps because they have characteristic topographic expressions and are otherwise more straightforward to map. Correlating lithologic units avoided the plethora of nomenclature conflicts from north to south. Our correlation (Figure 23) is similar to that of Tensi et al. [2006], who incorporated some age control. We used the Chinsui shale and equivalents as the regional datum for restoration because it corresponds to an easily recognized maximum flooding surface

Published thermochronological data were used to constrain the thermal history 
implied by the kinematics. The data were detrital apatite and zircon fission track ages, from Liu et al. [2001] and Fuller [2002] (Figure 3). The fission track data may be divided into reset, unreset and partially reset populations [Liu et al., 2001, Fuller, 2002]. A sample is unreset if both all grain ages and the central age are much older than the host's rock depositional age. A sample is totally reset if its grain ages are much younger than the age of the host rock and the age distribution is unimodal with no standard deviation. Between these two categories are the partially reset samples that have an intermediate span of grain ages [Liu et al., 2001].

Assuming constant cooling rates within the range of $1-100{ }^{\circ} \mathrm{C} / \mathrm{Ma}$, the effective track retention temperatures have been estimated at $135+/-20^{\circ} \mathrm{C}$ for apatite [Wagner and Reimer, 1972; Liu et al., 2001], and $235+/-20^{\circ} \mathrm{C}$ for zircon [Liu et al., 2001]. Based solely on the annealing properties of apatite, the partially reset samples would have had to reach temperatures on the order of $90-100^{\circ} \mathrm{C}$, while the unreset samples had to stay below $+/-60-80^{\circ} \mathrm{C}\left[\right.$ Fuller, 2002]. Additionally, muscovite $\mathrm{Ar}^{40} / \mathrm{Ar}^{39}$ ages and partiallyreset biotite $\mathrm{Ar}^{40} / \mathrm{Ar}^{39}$ ages in rocks from the Central Range indicate that the maximum temperatures experienced by these rocks are between $350-400^{\circ} \mathrm{C}$. These temperatures are consistent with the metamorphic greenschist facies conditions observed in the metamorphic pre-Tertiary basement rock of Taiwan [Liou and Ernst, 1984].

Assuming a surface temperature of $15^{\circ} \mathrm{C}$, and a geothermal gradient of about 20$25^{\circ} \mathrm{C}$, we estimate that the apatite fission track (AFT) data constrains partially reset samples to a maximum burial depth of $3-4 \mathrm{~km}$. With the same assumption, partially reset zircon fission track (ZFT) samples imply a maximum burial depth of 6-7 km. The 
$\mathrm{Ar}^{40} / \mathrm{Ar}^{39}$ ages from rocks of the Central Range imply a maximum depth of burial of 14 to $16 \mathrm{~km}$.

The AFT samples in the Western Foothills (Figure 3) show that while none of Miocene age samples are reset, they do show different degrees of annealing. The degree of annealing may be correlated either to stratigraphic position [Fuller, 2002], and/or to the position in fault blocks with different thermal histories. Additionally, $\mathrm{Ar}^{40} / \mathrm{Ar}^{39}$ ages in rocks from the Central Range constrain the geometry of faults and the amounts of vertical uplift. The existence of high-angle thrust faults would imply larger amounts of uplift than that expected for low-angle thrust for same amounts of shortening $(160 \mathrm{~km}$ [Suppe, 1980]). Therefore, we do not expect high-angle crustal scale faults involving amounts of uplift that would have reset the $\mathrm{Ar}^{40} / \mathrm{Ar}^{39}$ thermochronometers. A low angle regional detachment is more likely. Using geometric and thermal constraints, we estimated that the depth of the detachment beneath the Central Range is about $15-19 \mathrm{~km}$. This depth corresponds to the maximum depth of burial of the outcropping rocks (14-16 $\mathrm{km})$ plus the estimated thickness of the thrust sheets $(1-3 \mathrm{~km})$.

Below the Western Foothills, we placed a regional detachment surface between 10 and $15 \mathrm{~km}$ depth based on the relocation of small earthquakes by Carena et al. [2002]. The presence of this shallow regional detachment surface is in agreement with thermal data and must be the up dip extension of the regional detachment we estimate beneath the Central Range.

The kinematic model was integrated with geodetic data. We used the 3D GPS velocities of Wiltschko et al. [2002], supplemented by horizontal velocity vectors from 
Yu et al. [1997]. We correlated the current motion with accumulated displacement by projecting current velocity vectors on our cross sections. 


\section{DESCRIPTION OF STRUCTURES AND BALANCED CROSS SECTIONS}

We grouped the structures in three main areas. From north to south they are, the Taichung, Meishan, and Yuching areas (Figure 3).

\subsection{Taichung Area}

The main structures in the Taichung area (sections A-A' to D-D', Figures 4 to7), from foreland to hinterland are, 1) the Changhua thrust and associated TatushanPakuashan anticline, 2) the Chulungpu thrust, 3) the Schuantung fault and, 4) the Schuiangliu or Tulungwan fault. The Taichung area is also characterized by a thickening of the Upper Pliocene and Pleistocene units compared with the thickness observed toward the south.

\subsubsection{The Changhua Thrust}

The Changhua thrust is the westernmost structure of the Western Foothills fold and thrust belt and constitutes the deformation front. The maximum displacement estimated for this thrust is $2.2 \mathrm{~km}$ along section A-A' (Figure 4), decreasing toward the south. The axial traces of the Tatushan and Pakuahsan anticlines are arcuate and follow the shape of the Peikang high. The equivalent structure in the Meishan Area is the Meilin anticline (Cross section D-D', Figure 7). Little to no deformation propagates west of this group of structures into the Coastal Plain.

\subsubsection{The Chelungpu Thrust}

The Chelungpu fault is the emergent frontal thrust in the Taichung area. The Chelungpu thrust sheet is bound to the east by Shuangtung fault system. Its footwall is the Coastal Plain. The Chelungpu fault ruptured during the Chi-Chi earthquake $(M=7.6)$ 
in September $21^{\text {st }} 1999$ [Chang et al., 2000]. The monocline on its hanging wall is a fault-bend fold that in map view shows a flat on ramp detachment along the Chinsui shale. This Chinsui shale detachment crops out parallel to the Chelungpu fault (Figure 3). In addition, the Chelungpu thrust has at least another detachment in a lower stratigraphic level, probably the Talu shale. The latter is suggested by the presence of the Kueichulin formation that crops out on the northern portion of the Chulungpu fault [Chang, 1971] and therefore, must be restored to a lower stratigraphic position than the Chinsui shale. The Chelungpu fault looses displacement south of the Choshui River (point b, Figure 17) where its hanging wall syncline plunges toward the south, (closure around $23^{\circ} 45^{\prime}$ [CPC, 1986]), at the Chinsui shale level. About $20 \mathrm{~km}$ of displacement is transferred from the Chelungpu and Schiangliu thrusts to the Tachienshan fault in front of the Peikang high. The Chelungpu thrust is listric, dipping up to $45^{\circ}$ on its shallower portions. The maximum displacement estimated for the Chelungpu thrust is $15 \mathrm{~km}$ in section A-A' (Figure 3), decreasing to $13 \mathrm{~km}$ in section B-B' (Figure 5), $11.6 \mathrm{~km}$ section C-C' (Figure 6) and $8 \mathrm{~km}$ in section D-D' (Figure 7).

We interpret the presence of a deeper fault, here called Chi-Chi fault, on which slip took place during the Chi-Chi earthquake. The Chi-Chi fault links at depth with the Chelungpu fault and can be interpreted as an inverted extensional fault. We base our interpretation on the following reasons. First, the focal depth for the Chi-Chi earthquake $(10 \mathrm{~km}+/-0.5 \mathrm{~km}$ depth [Kao et. al., 2000]) is deeper than the Chelungpu fault and must be interpreted as a different fault. Second, there are well-documented Paleogene extensional faults along Taiwan [Sibuet and Hsu, 1997, Chou and Yu, 2002, Lin and 
Watts, 2002, Lin et al., 2003] and some seismic evidence of inverted normal faults [Chou and $Y u, 2002]$. Consequently, the existence of normal faults beneath the Western Foothills is not only possible but likely. Third, the surface expression of the Chi-Chi subsurface rupture occurred along the Chelungpu fault. Since the Chi-Chi and Chelungpu must be two different faults, we suggest that the Chi-Chi fault and the Chelungpu fault join in the subsurface. This interpretation is reflected in sections A-A' to $\mathrm{C}-\mathrm{C}^{\prime}$ (Figures 4 to 6 ).

The Chi-Chi fault must have a small cumulative displacement in order to not create significant, and not observed, surface deformation such as second order folding in the Chelungpu thrust sheet (Section A-A', B-B', C-C', Figures 4 to 7). We give the ChiChi fault a maximum displacement of $600 \mathrm{~m}$ to honor this constraint.

Toward the south, the Chelungpu thrust seems to be truncated by the Tachienshan thrust (sections D-D', E-E', Figures 7 and 8).

\subsubsection{The Schuangtung Fault}

The Schuangtung fault exposes rocks as old as Oligocene within the Tsukeng Anticline and Eocene rocks Schuangtung thrust sheet (Figure 3). These Eocene and Oligocene rocks are considered basement rocks from the Slate Belt. The Eocene and Oligocene rocks have incipient metamorphism, as can be inferred by the presence of slaty shales and arkosic sandstones with small amounts of muscovite [Chiu, 1975]. One remarkable feature associated with this fault is the large change in stratigraphic thickness across it. The Oligocene units within the Schuangtung upper plate are at least $1.7 \mathrm{~km}$ thick which is almost double of the thickness found in PKS-1 well (about $0.9 \mathrm{~km}$, 
Section A-A', Figure 4). The north-south Tahengpingshan syncline and its anticline pair are the main structures associated with the Schuangtung fault. Minor splays cut and refold the Tahenspinshan syncline in several segments. We modeled the east limb of the Tahenspinshan syncline as the front limb of the frontal-most anticline of the slate belt. This anticline is broken on its back-limb by the out of sequence Schuiangliu (Tulungwan) fault that gains displacement from this point toward the south. The exposed rocks on the hanging wall of the Schuangtung fault are the oldest and most thermally mature rocks of the WFFTB, showing evidence of very-low grade metamorphic conditions. The displacement on the Schuangtung fault varies from $20.7 \mathrm{~km}$ in section A-A' (Figure 4), in the north, to a maximum in section B-B' of $22.8 \mathrm{~km}$ (Figure 5). The displacement decreases toward the south to $14.5 \mathrm{~km}$ in section C-C' (Figure 6), and 10.5 $\mathrm{km}$ in section D-D’ (Figure 7).

\subsubsection{The Tulungwan Fault}

The Tulungwan fault carries a number of low-grade metamorphosed hinterland imbricates and is the boundary between the Slate Belt and the Western Foothills. This fault system may be interpreted as a low angle thrust. It begins as an out-of-sequence thrust that breaks the backlimb of a basement cored anticline at $24^{\circ} 10^{\prime}$ (around point $\underline{\mathbf{a}}$ in Figure 3). At this point the Paileng Fm (Eocene) underlies sedimentary rocks from the foothills Neogene sedimentary cover. The complete sequence from Eocene to OligoMiocene foothills sediments is present there. The throw is less than $100 \mathrm{~m}$ in most the northern area because the fault juxtaposes the Shithi Fm against the Peiliao Mb (Figure 23) omitting the Peiliao Mb, which is about 100 m thick. The Tulungwan fault increases 
displacement from this northern tip to the south. In the segment between $23^{\circ} 42^{\prime}$ and $23^{\circ} 33^{\prime}$ there is a change in the strike of this fault from N10E to N30W. This change in orientation can be interpreted as either an oblique ramp or a relay ramp where displacement is transferred from the Tulungwan fault to the Chaochou fault. The position of this oblique feature also corresponds in latitude with both the approximate northern extent of the Peikang High and the southern extension of the Hsuehshan range. From this oblique ramp segment toward to the south this fault (or its equivalent) is called of Chaochou fault.

\subsection{The Meishan Area}

The main structures in the Meishan Area are the Meilin anticline, the Tachienshan fault, the Luku fault and the Tulungwan-Chaochou fault.

\subsubsection{The Meilin Anticline}

South of the Chousui river (point b, Figure 3), the Meilin anticline occupies an equivalent structural position to that of the Pakuashan anticline. However, based on both well data and previous interpretations [Suppe and Namson, 1979] we interpret this anticline as a fault propagation fold. The best geometric fit to the available data is obtained if the anticline grows in two stages. The first stage of growth is by fault propagation folding with $4 \mathrm{~km}$ of displacement and the second stage is by fault bend folding with $1.4 \mathrm{~km}$ of displacement. The southern part of the Meilin anticline ends abruptly against a transverse fault we interpreted as a transfer fault because there is a change in vergence of the equivalent structure toward the south. 


\subsubsection{The Tachienshan Fault System}

The Tachienshan fault is the frontal emergent thrust in the Meishan area (Figure 3). From the Choshui River (point b, Figure 3) to the south this fault increases displacement from $9 \mathrm{~km}$ in section C-C' (Figure 6) to $14 \mathrm{~km}$ in section D-D' (Figure 6), $20.5 \mathrm{~km}$ in section E-E' (Figure 8), to a maximum of $24 \mathrm{~km}$ in section F-F' (Figure 9). The displacement decreases again to the south to $21.5 \mathrm{~km}$ in section G-G' (Figure 10) and $15 \mathrm{~km}$ in section H-H' (Figure 11). From the Yuching area to the south the Pingchi fault occupies an equivalent structural position to the Tachienshan fault. The Tachienshan fault can be interpreted either as an out-of-sequence thrust, or an out-ofsequence reactivation of an existing thrust. This out-of-sequence interpretation is inferred from balanced cross sections and from the geologic map in which we observe that the fault trace becomes significantly displaced toward the west. In addition, the Tachienshan thrust cuts the Chulungpu fault and the Chukou and Lunhou faults in the northern and southern parts of the Meishan area, respectively. The increase in displacement on the Tachienshan fault coincides with the decreasing of displacement in the Chelungpu fault in the Taichung area. The area of maximum displacement along the Tachienshan thrust coincides with its closest position to the Peikang High. The exhumation level of the hanging wall of the Tachienshan fault remains constant south of the Chosui river. No rocks older than Miocene (Nankang and Nanchuang Fm and equivalents) are currently exposed. Moreover, AFT data shows unreset samples of apatite for this area. The AFT results suggest that these rocks were never buried deeply enough to anneal the apatite fission tracks. Previous interpretations involve stacks of 
imbricate thrusts sheets with Miocene rocks coming from depths of 6-8 $\mathrm{km}$ [Hung et al., 1999, Yang et al., 2007]. We instead interpret the Tachienshan fault as an inverted fault with a footwall shortcut. The Tachienshan fault evolved in two stages. First, after the deposition of the Chinsui shale in the Upper Pleistocene, the Tachienshan fault generated enough relief to impede the deposition of enough Plio-Pleistocene sediments (Cholan Fm, Figure 23) to reset the AFT samples. Second, it was reactivated in an out-ofsequence manner that is synchronous with the deposition of the upper Pleistocene and quaternary sediments (Toukoshan Fm. and younger sediments, Figure 23).

Even though the velocity vector orientations from GPS are parallel to faults in most cases on the Western Foothills, there is a zone of anomalous velocities on the hanging wall of the Tachienshan fault (Figure 3). The vertical component in the anomalous velocity zone, indicates a downward direction of displacement (section E-E' to H-H', Figures 8 to 11 ) with magnitudes up to $70 \mathrm{~mm}+/-7 \mathrm{~mm}$.

South of $23^{\circ} 22^{\prime}$ the Tachienshan fault has an oblique ramp and decreases in displacement. The latter oblique ramp seems to be cutting the Chukou and Lunhou faults in an out-of-sequence relationship.

\subsubsection{The Fenghuachan-Luku Fault}

We treat these two faults as one because, 1) they have an equivalent structural position and 2) their surface trace is aligned on-strike in map view. There is a large change in stratigraphic thickness across of the Fenghuachan-Luku fault. This change in thickness is evident on cross section E-E' (Figure 8), where the restored position of the topography in the hanging wall of the Luku fault implies a thicker Miocene section (at 
least $3 \mathrm{~km}$ ) than that encountered in MLN-1 well (about $0.6 \mathrm{~km}$ ). The displacement of the Luku fault increases toward the south, from $10.5 \mathrm{~km}$ in section D-D' (Figure 7) to $10.8 \mathrm{~km}$ in section E-E' (Figure 8) to a maximum of $16 \mathrm{~km}$ in section F-F' (Figure 9), and decreasing to 12.8 in section G-G (Figure 10). South of section G-G' (Figure 10), the Luku fault seems to be cut by the Tachienshan fault. This can be inferred from both the Luku's fault displacement profile (Figure 18), and the fact that the Luku fault truncates against the southern oblique ramp of the Tachienshan fault (Figure 17).

\subsubsection{The Tulungwan Fault}

The Tulungwan or Chaochou fault seems to be increasing in displacement from south of the Taichung area to the Meishan area. From the Meishan area to the south, the Chaochou fault decreases in displacement. This decrease in displacement and strain intensity has been inferred by Hassler [2004] in southern Taiwan based on: 1) the absence of rotational strain indicators such as sigmoidal quartz fringes and, 2) the metamorphic grade of the Slate Belt and, 3) the intensity of strain in the outcropping rocks on the hanging wall the Tulungwan-Chaochou fault decreases toward its south portion, as well as the amount of active uplift.

\subsection{Yuching Area}

The main structures in the Yuching area are the Chukou, Lunhou, Pingchi, Chishan, Sub-Yuching and Chaochou faults.

\subsubsection{The Chukou and Lunhou Faults}

In the Yuching area, the Tachienshan fault looses displacement and the dominant structures are the Chukou and Lunhou faults and their associated structures, the Yuching 
and Tingpinglin synclines. The Chukou fault is modeled as a fault bend fold. In the southern part of the Yuching area it breaks the back-limb of a fault propagation fold, increasing displacement from $2.2 \mathrm{~km}$ in section M-M' (Figure 16) to $6.5 \mathrm{~km}$ in section II' (Figure 12). The Chukou fault shows the maximum displacement $(15 \mathrm{~km})$ and exposes the oldest rocks on the Chukou thrust sheet (Nankang Fm, Figure 23) along section H-H' (Figure 11). The Yuching syncline is actively growing; both of the limbs of the syncline are moving toward the axial surface and are being uplifted at a greater rate than the fold axis [Hickman et al., 2002]. The Lunhou fault is also modeled as a fault bend fold. It increases displacement from $80 \mathrm{~m}$ in section M-M' (Figure 16), where it begins breaking the back-limb of a fault propagation fold, to about $9.8 \mathrm{~km}$ in section I-I' (Figure 12). The Lunhou fault is modeled as a duplex structure in sections I-I' and J-J' (Figures 12 and 13) in order to explain the highly inclined dips on the eastern limb of the Tingpinglin syncline. An alternate model would include a fault propagation fold. However, a fault propagation fold would imply a deeper detachment level than that estimated for the neighboring cross sections. In addition a fault propagation fold would create a different structural style than the one observed in the area. At the south end of the Yuching area the displacement along the Lunhou fault die out and the displacement along the Chukou fault decreases to the south. The remaining displacement along the Chukou fault is transferred to the hinterland through a lateral ramp.

At the northern part of the Yuching area around $23^{\circ} 22^{\prime}$, the Tachienshan fault cuts the Chukou and Lunhou faults in an out-of-sequence relationship. This out-of sequence relationship can be inferred from the following. First, the geologic map (Figure 
6) indicates that the Tachienshan fault truncates the Chukou and Lunhou faults. Second, displacement profiles (Figure 18) show a truncation in the displacement of the Chukou and Lunhou faults against the Tachienshan faults. Third, from the cross sections it is not possible to continue the Chukou and Lunhou faults from section H-H' to G-G' (Figures 11 and 10) to due to changes in stratigraphic thicknesses and structural style. Also, the juxtaposition of units across the Tachienshan fault shows a reverse fault relationship along most of its trace (i.e., Figure 17-C, points b and c), except in the intersection between the Chukou and Lunhou faults, where it shows a normal fault juxtaposition relationship (Figure 17-C, point b).

\subsubsection{The Sub-Yuching Fault}

By comparing elevations of the Chinsui shale (or equivalents) we found that: 1) the Yuching and Tingpinglin synclines are uplifted with respect to the regional level, and 2) the footwall of the Chukou fault is, in general, a wide panel dipping toward the west. This dipping panel can be described as a frontal monocline along the footwall of the Chukou fault. To explain the regional uplift of the Yuching and Tingpinglin synclines and the frontal monocline on the footwall of the Chukou fault, we propose the presence of a basement cored anticline that detached at 10-13 km (sections M-M' to G-G', Figures 16 to 10). We will call this structure the sub-Yuching anticline. It is modeled as a fault bend fold with a maximum displacement of $11.5 \mathrm{~km}$ in section J-J' (Figure 13). The displacement along the sub-Yuching fault decreases both north and south (Figure 17). The forelimb of the sub-Yuching structure explains the frontal monocline located in the footwall of the Chukou fault. There are minor folds associated with this forelimb. 
These minor folds are interpreted as part of an intercutaneous wedge resting above and linked to the roof thrust of this wedge (e.g. Section J-J', Figure 13) The wedge transfers displacement from the sub-Yuching fault toward the front limb. The sub-Yuching anticline also explains the uplift of the Yuching and Tingpinglin synclines above regional, because these two structures rest over the wide and flat crest of the subYuching anticline.

An alternative interpretation to explain this regional uplift is the presence of an antiformal stack of sub-thrust duplexes beneath the Yuching and Tingpinglin synclines. However, if this were the case, a stack of duplexes might cause interference folding, reflecting the structural thickening underneath. Also if the Chukou and Lunhou faults are stacked thrusts [Hickman et al., 2002] it would imply more vertical uplift (about $8 \mathrm{~km}$ ) than that inferred from the fission track data (Figure 3). Finally, a stack of thrusts would imply larger horizontal displacements. This is not consistent with the fact that displacement decreases to the south along the Chukou and Lunhou faults.

\subsubsection{The Pingchi and Chishan Faults}

The Pingchi fault is the eastern boundary of the Tingpinglin syncline. The Pingchi thrust sheet is characterized by the wide Chiahsien syncline. The Miocene in this sheet is thicker than that in the Chukou and Lunhou faults. This thickening is interpreted to be a consequence of being on the hanging wall of a normal fault. The eastern part of the Chiahsien syncline is cut by the Chishan fault. The rocks within the Chishan thrust sheet also show stratigraphic thickening and partially reset AFT ages (Figure 3). The thermal maturity of this rock is due to its location in a deeper part of the basin subjected to more 
overburden [Fuller, 2002]. Towards the south of the Chukou fault lateral ramp this faults gains displacement. 


\section{THREE-DIMENSIONAL MODEL}

A three-dimensional model was constructed based on 13 balanced cross sections and 3 additional transverse sections. Due to stratigraphic complexity in the WFFTB we decided to limit our model to the main faults. Figures 20 to 22 show different perspective views of the three-dimensional model. 


\section{DISCUSSION}

Previous structural models have characterized the thrust belt of Taiwan either as a purely thin-skinned [Suppe, 1981, 1987] or thick-skinned thrust belt [Lee et al., 2002]; only a few authors have proposed a combination of these two styles [Mouthereau et al., 2002]. We propose that the structural style of the Western Foothills fold and thrust belt may be better characterized as thrust faulted and inverted basin. The thrust belt architecture is dominated by inverted normal faults, footwall shortcuts, hanging wall shortcuts and low angle thrusts.

The orogen geometry in general is influenced by the pre-existence of extensional structures like normal faults and basement horsts. In our cross sections we interpreted several normal fault sets. These sets where placed in areas where changes in stratigraphic thicknesses required the existence of a normal. A set of normal faults is placed in front of the Peikang high because a stratigraphic expansion is reported between this location and the Western Foothills [Ho, 1971; Sun, 1985; Shaw, 1996]. The remaining normal faults are usually placed in intermediate positions between the foreland and the restored normal faults located toward the hinterland. Most of these faults are merely interpretative and placed in order to continue the sub-thrust structural style where no data exist.

The presence of Cenozoic rift basins has been well documented in the continental shelf offshore and onshore Taiwan [Sibuet and Hsu, 1997]. Sibuet and Hsu [1997] identified four rift belts parallel to the main Eurasian shoreline, interpreting these basins as being younger oceanward. They identified four rifting phases that occurred during 
Paleocene, Eocene, Oligocene to Early Miocene and early Middle Miocene to Present. In addition, the geometry and magnitude of normal faults has been extensively documented beneath the coastal plain from seismic profiles [Yu and Chou, 2001, Chou and Yu, 2002, Lin et al., 2003]. Some of these normal faults should be expected to be reactivated during the collision and some inverted normal faults have been shown in seismic profiles [Figure 8 in Chou and $Y u, 2002$ ]. Most dramatically, the Hsuehshan range is commonly interpreted as an invert graben [Barrier and Angelier, 1986]. We interpreted some reverse faults as inverted normal faults based on the presence of noticeable differences in stratigraphic thicknesses across the fault. One example of this is the difference on thicknesses on the Miocene units across the Tachienshan and Pingchi faults. Another indication of the existence of an inverted fault is their map expression. One example is the southern oblique ramp of the Tachienshan fault. In this segment both normal and reverse fault age relationships are found (Figure 17-C point a normal, points $\mathrm{b}$ and $\mathrm{c}$ reverse). A similar situation where a normal fault is transported on a trust sheet as a footwall shortcut is found in the Schuangtung thrust sheet (Figure 17-B and Cross Section C-C, Figure 6).

The average thrust displacement estimated for the Western Foothills fold and thrust belt is about $40 \mathrm{~km}$. It decreases slightly toward the south of the Yuching area. Our estimation accounts mostly for the Western Foothills displacement and is less than previous estimations in northern Taiwan of $160 \mathrm{~km}$ across the orogen [Suppe, 1980]. We did not estimate shortening east of the Western Foothills.

We restored the transported normal faults to their original position. The restored 
position of the normal faults found in the cross sections moves the easternmost interpreted normal faults about $40 \mathrm{~km}$ toward the east. Consequently, the current surface trace of the Tuluwang-Chaochou fault originated below the present position of the Coastal Range (Figure 19). This restoration contradicts the idea of predominantly vertical uplift of a deep-rooted Central Range [Wu et al., 1997]. The restored position of the normal faults to their pre-transported position involves mainly horizontal displacement based, at least, on the thermochronologic data that indicate that the rocks from the Central Range were never above $400^{\circ} \mathrm{C}$ during the Tertiary. The evidence is the lack of reset high-temperature thermochronometers $\left(\mathrm{Ar}^{40} / \mathrm{Ar}^{39}\right.$ hornblende and muscovite) and the presence of partially reset biotite $\mathrm{Ar}^{40} / \mathrm{Ar}^{39}$ ages. In a deep-rooted Central Range hypotheses, the exhumation would involve mostly vertical uplift of rocks coming from $20-25 \mathrm{~km}\left(500-600^{\circ} \mathrm{C}\right.$ [Willett et al., 2003]). Those amounts of vertical uplift are not shown by thermochronologic data [Willett et al., 2003].

The thrusting sequence on the Western Foothills is not strictly forward breaking. Out of sequence faulting is common as indicated by current seismic activity, balanced cross sections and map considerations. The Chelungpu fault, which is not the leading edge thrust on the Western Foothills, is a well-documented example of out of sequence faulting during the Chi-Chi earthquake [Kao et al., 2000]. Hung et al. [1999], also show that the Sanyi thrust ought to be an out-of sequence thrust. GPS velocities show that most of the faults are accumulating strain, and seismicity data shows that the leading edge thrust is not the only one that is currently active. Therefore, while the start or initiation of each major thrust may be in sequence (east to west), their continued 
displacements are not, especially in the context of the earthquake cycle.

There is a zone along the hanging wall of the Tachienshan fault that shows a group of GPS sites with negative (downward) vertical velocities (Figure 3). The anomalous velocities could be explained as a measurement error if it were just one site, or they can be attributed to subsidence. If there is subsidence, it should be possible to find recent sedimentary deposits or geomorphic features as indicators; however this idea has not been tested in the field. The existence of subsidence is difficult to explain here. Some hypotheses for this could include: 1) this subsidence is a short term effect related to the seismic cycle, 2) the subsidence is related to accommodation in the frontal fold by shear in the Meilin anticline.

The sub-Yuching structure may lie above the extension of the Manila Trench. The sub-Yuching structure in the southern Foothills is a low angle thrust with a detachment located at $\sim 13 \mathrm{~km}$ depth. This regional low angle thrust lies below the Yuching and Tingpinglin synclines to account for the elevation of these structures over their regional level. This structure has a wide crest over which Tingpinglin and Yuching synclines are positioned. Its front limb explains a long monocline found in the southern Foothills on the footwall of the Chukou fault. This structure is compatible with both FT data, which imply about $3 \mathrm{~km}$ of vertical uplift, and focal mechanisms. The geometry and orientation of the sub-Yuching thrust suggest the possibility that it is equivalent of the northern extension of the Manila Trench. This idea agrees with several authors who place the continuation of the Manila trench as the leading edge of the Western Foothills fold and thrust belt [Teng, 1990, Teng et al., 2000, Lallemand et al., 2001]. This leading edge is 
overthrusting the Western Foothills over the Chinese continental margin.

The idea of trading space for time in Taiwan appears to be in jeopardy. Thermochronologic evidence shows that the onset of the mountain building is roughly the same from north to south, $6 \mathrm{Ma}$ [Lee et al., 2006]. Also, the structural configuration is highly influenced by the pre-existing geometry of the basin, and there is evidence of inverted faults that were not developed in-sequence. One consequence of the latter is that there is not a strict sequence of deformation and out-of sequence faulting is common. Therefore changes in the structural style along the strike of the Western Foothills are common and is difficult extrapolated a cross section in space and time.

The timing for the western foothills of Taiwan is constrained by unconformities and thermal data. The three main unconformities are at the upper Miocene (Tangenshan Fm. and equivalents, Figure 23), Upper Pliocene (Cholan formations and equivalents, Figure 23) and Middle Pleistocene (Toukoshan Fm and equivalents, Figure 23). From the cross section restoration and thermal data we can infer at least two cooling events. The AFT samples from the Western Foothills were samples from Miocene rocks. For the non-reset AFT samples in the Western Foothills, we assume that those rocks never were buried more than 3-4 km whereas partially reset samples were at one time deeper [Fuller, 2002].We interpret that the Cholan formation and equivalents were partially or not deposited over the over the Chinsui Fm. The cause for not deposit these rocks was lack of accommodation caused by to uplift. This uplift may be caused by an early activity of the faults and before the deposition of the Cholan formation. One interpretation can be that some faults like the Tachienshan, Schuangtung and Pinghchi 
faults start their activity between 6 and $3 \mathrm{Ma}$ and were reactivated from 1.5 Ma to the present day, as indicated by the deposition of molasse sediments from the Upper Pleistocene to present. This interpretation fits with the thermal data and our kinematics interpretation. 


\section{CONCLUSIONS}

1. The structural style of the Western Foothills fold and thrust belt can be defined as a thrusted and inverted basin.

2. The average total thrust displacement estimated for the Western Foothills fold and thrust belt is about $40 \mathrm{~km}$.

3. The Central Range is a crustal-scale thin-skinned thrust belt. The restored position of the normal faults, as well as the thermochronologic data shows that the amounts of vertical uplift reached in the Central Range are in agreement with an horizontal component as the main component of tectonic transport.

4. The presence of basement highs like the Peikang High modifies the geometry and timing of thrusting in the Western Foothills. The axial trace geometry of the Neilin and Pakuashan anticline, as well as the out-of-sequence reactivation of the Tachienshan fault are interpreted as related to the Peikan High

5. A new regional structure, the sub-Yuching structure is identified in the southern Western Foothills of Taiwan. This structure explains the regional uplift of the Yuching and Tingpiglin synclines, as well as the monocline along the footwall of the Chukou fault. This structure may be the northern extension of the Manila trench.

6. The Tachienshan, Schuangtung and Pinghchi faults in the Western Taiwan started activity before the deposition of the Cholan Fm between 6 and 3 Ma 3.3 Ma. These faults were reactivated from about 1.5 Ma to the present day, as indicated by the deposition of molasse sediments from the Upper Pleistocene to 
present. If the Cholan Fm and Toukoshan Fm were deposited in the entire Western Foothills they were provided enough overburden to partially or totally reset the AFT samples. 


\section{REFERENCES}

Barrier, E., and J. Angelier (1986), Active collision in eastern Taiwan: the Coastal Range, Tectonophysics, 125, 38 - 72.

Carena, S., Suppe, J., and H. Kao (2002), The active detachment of Taiwan illuminated by small earthquakes and its control of first-order topography, Geology, 30, 935-938.

Chang, C.-H., Y.-M, Wu, T.C. Shin, and C.-Y. Wang (2000), Relocation of the 1999 Chi-Chi Earthquake in Taiwan, TAO, 11, 3, 581-590.

Chang, S.-C., C.-S., Tseng, P.-K. Torng, and K.S. Lee (1998), A proposed interpretation of Neogene lithostratigraphy on Western Foothills area, southern Taiwan, Petroleum Geology of Taiwan, 32, 87 - 103.

Chang, S.L. (1971), Subsurface geologic study of the Taichung Basin, Taiwan. Petroleum Geology of Taiwan, 8, 21 - 45.

Chemenda, A.I., R.K. Yang, C.-H. Hsieh, A.L. Groholsk (1997), Evolutionary model for the Taiwan collision based on physical modeling, Tectonophysics, 274, 253-274.

Chiai, B.H.T. (1972), Structure and tectonic evolution of Taiwan, Am. J. Sci., 272, 389442.

Chinese Petroleum Company - CPC (1986), Geologic map No.5, Chia-i. Esc: 1:100000. Taiwan Petrolem Exploration Division, Chinese Petroleum Company, Taipei, Taiwan.

Chinese Petroleum Company - CPC (1989), Geologic map No.6, Tai-Nan. Esc: 1:100000. Taiwan Petrolem Exploration Division, Chinese Petroleum Company, Taipei, Taiwan. 
Chiu, H.T. (1975), Miocene stratigraphy and its relation to the Palaeogene rocks in West-Central Taiwan, Petroleum Geology of Taiwan, 12, 51-80.

Chou, J.T. (1973), Sedimentology and paleogeography of the upper Cenozoic system of western Taiwan, Proc. Geol. Soc. China, 16, 111-143.

Chou, J.T. (1980), Stratigraphy and sedimentology of the Miocene in western Taiwan. Petroleum Geology of Taiwan, 17, 33-52.

Chou, Y.-W., and H.S. Yu (2002), Structural expression of flexural extension in arccontinenent collisional foredeep of western Tawain, Geological Society of America Special Paper, 358, 1-12.

Dadson, S.J., N. Hovius., H. Chen., W. B. Dade., M. L. Hsieh., S. D. Willettt., J. C. Hu., M. J. Horng., M. C. Chen., C. P. Stark., D. Lague., and J. C. Lin (2003), Links between erosion, runoff variability and seismicity in the Taiwan orogen, Nature, 426, $648-651$.

Dahlen, F.A., and T.D. Barr (1989), Brittle frictional mountain building 1. Deformation and mechanical energy budget, Journal of Geophysical Research, 94 (B4), 39063922.

Environmental Systems Research Institute - ESRI (2007), ArcGlobe-ArcView 9.2 [Software], Redlands, California.

Fuller, C. W., (2002), Thermochronometry and thermomechanical modeling of the Taiwan Orogen, M.S. thesis, 82 pp., University of Washington.

Hassler, L. (2004), Motion and evolution of the Chaochou fault, southern Taiwan, M.S. thesis, 54 pp., Texas A\&M University. 
Hickman, J.B., D.V. Wiltschko, J.-H. Hung, P. Fang, and Y. Bock (2002), Structure and evolution of the active fold-and-thrust belt of southwestern Taiwan from GPS analysis, in Geology and Geophysics of an Arc-Continent Collision, Taiwan, Geological Society of America Special Paper, 358, 75-92.

Ho, C. S. (1971), The Tertiary basins of Taiwan, Bull. Geol. Surv. Taiwan, 23,1-52.

Ho, C. S. (1986), A synthesis of the geologic evolution of Taiwan. Tectonophysics, 125, $1-16$.

Ho, C. S. (1988), An introduction to the geology of Taiwan: explanatory text of the geologic map of Taiwan (2nd ed.), 164 pp., Ministry of Economic Affairs, R.O.C.

Huang, S. T., Yang K.-M., Hung, J.-H., Wu, J.-C., Ting, H.-H., Mei, W.-W., Hsu, S.-H., and M, Lee (2004), Deformation front development at the northeast margin of the Tainan basin, Tainan-Kaohsiung area, Taiwan, Marine Geophysical Researches, 25, $139-156$.

Hung, J.-H., Wiltschko, D.V., Lin, H.-C., Hickman, J., Fang, P. and Bock, Y. (1999), Structure and motion of the southwestern Taiwan fold and thrust belt, TAO, 10, 543568.

Kao, H., Chen, R.-Y., and Chang, C.-H. (2000), Exactly where does the Chi-Chi earthquake nucleate? - Hypocenter relocation using the Master Station method, Terr. Atmos. Oceanic Sci., 11, 567-580.

Lallemand, S.E., and H. Tsien (1997), An introduction to active collision in Taiwan. Tectonophysics, 274, 1-4. 
Lallemand, S. E., Y. Font, H. Bijwaard, and H. Kao (2001), New insights on 3-D plates interaction near Taiwan from tomography and tectonic implications, Tectonophysics, $335,229-253$.

Lee C.I.,Y.-L. Chang, and M. P. Coward (2002), Inversion tectonics of the fold-andthrust belt, western Taiwan, Geological Society of America Special Paper, 358, 1330.

Lee, Y.-H., C.-C., Chen, T.-K., Liu, H.-C., Ho, H.-Y. Lu., and W. Lo (2006), Mountain building mechanisms in the Southern Central Range of the Taiwan orogenic belt. From accretionary wedge deformation to arc-continental collision, Earth and Planetary Science Letters, 252, 413-422.

Lin, A.T. and A.B. Watts (2002), Origin of the West Taiwan Basin by orogenic loading and flexure of a rifted continental margin, J. Geophys. Res., 108: ETG2-1-2-19.

Lin, A.T., Watts, A.B. and S.P. Hesselbo (2003), Cenozoic stratigraphy and subsidence history of the South China Sea margin in the Taiwan region, Basin Research, 15, 453-478.

Liu, C.-H., (1995), Geodetic monitoring of mountain building in Taiwan (abstr.). Eos, Trans, AGU, 76 (636).

Lin C.-H., (2002), Active continental subduction and crustal exhumation: the Taiwan orogeny, Terra Nova 14, 4, 281-287.

Liou, J.G., and W.G. Ernst (1984), Summary of Phanerozoic metamorphism in Taiwan, Memoir of the Geological Society of China, 6, 133-152. 
Liu, T.-K., S. Hseih, Y.-G. Chen, and W.-S. Chen (2001), Thermo-kinematic evolution of the Taiwan oblique-collision mountain belt as revealed by zircon fission track dating, Earth and Planetary Science Letters, 186, 45-56.

Lundberg N., D.L. Reed, C.-S. Liu, and J. Lieske,Jr (1997), Forearc-basin closure and arc accretion in the submarine suture zone south of Taiwan, Tectonophysics, 274, 523.

Malavieille, J., S.E. Lallemand, S. Dominguez, A. Deschamps, C.-Y. Lu, C.-S. Liu, P. Schnurle, and A.S. Crew (2002), Arc-continent collision in Taiwan : new marine observations and tectonic evolution, Geological Society of America Special Paper, $358,189-213$.

Mouthereau, F., O. Lacombe, B. Deffontaines, J. Angelier, and S. Brusset (2001), Deformation history in the southwestern Taiwan foreland thrust belt: insights from tectono-sedimentary analyses and balanced cross-sections, Tectonophysics, 333, 293322.

Mouthereau, F., Deffontaines, B., Lacome, O., Angelier, J. (2002), Variation along the strike of the Taiwan thrust belt, basement control on structural style, wedge geometry and kinematics, Geological Society of America Special Paper, 358, 31-53

Seno, T. (1977), The instantaneous rotation vector of the Philippine Sea plate relative to the Eurasian plate, Tectonophysics, 42, 209-226.

Seno, T., S. Stein, and A.E. Gripp (1993), A model for the motion of the Philippine Sea plate consistent with NUVEL-I and geologic data, J. Geophys. Res., 98, B10:17,941 17,948 . 
Shaw, C.L. (1996), Stratigraphic correlation and isopach maps of the western Taiwan Basin, Terr. Atmos. Ocean. Sci., 7, 330-660.

Sibuet, J.-C., and S.-K. Hsu, (1997), Geodynamics of the Taiwan arc-arc collision, Tectonophysics, 274,221-251.

Sun, S.C., (1985), The Cenozoic tectonic evolution of offshore Taiwan, Energy, 10, 421432.

Suppe, J. (1980), A retrodeformable cross section of northern Taiwan, Proc. Geol. Soc. China, 23, 46-55.

Suppe, J. (1981), Mechanics of mountain building and metamorphism is Taiwan, Mem. Geol. Soc. China, 4, 67-89.

Suppe, J. (1984), Kinematics of arc-continent collision, flipping of subduction and backarc spreading near Taiwan, Mem. Geol. Soc. China, 6, 21-34.

Suppe, J. (1987), The active Taiwan mountain belt, in Anatomy of mountain chains: edited by J.P., Schaer, and J., Rodgers, pp. 277-293, Princeton University Press, Princeton, New Jersey.

Suppe, J. and J. Namson (1979), Fault-bend origin of frontal folds of the Western Taiwan fold-and-thrust belt, Petroleum Geology of Taiwan, 16, 1-18.

Tang, J.C. and A.I. Chemenda (2000), Numerical modeling of arc-continent collision: application to Taiwan, Tectonophysics, 325, 23-42.

Teng, L. (1990), Geotectonic evolution of late Cenozoic arc-continent collision in Taiwan, Tectonophysics, 183, 57-76. 
Teng, L.S., C.-T., Lee, Y-B. Tsai, and L.-Y. Hsiao. (2000), Slab break-off as a mechanism for flipping of subduction polarity in Taiwan, Geology, 28, 2,155-158.

Tensi, J., F. Mouthereau and O. Lacombe (2006), Lithospheric bulge in West Taiwan basin. Basin Research, 18, 3, 277-299.

Tsai, Y.B. (1986), Seismotectonics of Taiwan, Tectonophysics, 125, 17-37.

Wagner, G.A. and G.M. Reimer (1972), Fission track tectonics: The tectonic interpretation of fission track apatite ages, Earth and Planetary Science Letters, 14, $263-268$.

Willett, S.D., Fisher, D., Fuller, C., Yeh, E-C., and C.Y. Lu (2003), Orogen Kinematics and Erosion Rates in Taiwan from Thermochronometric Data, Geology, 3, 1, 11, 945948.

Wiltschko, D.V., J.H. Hung, P. Fang, and Y. Block (2002), Motion along the EurasianPhilippine Sea Plate boundary in the Longitudinal valley, Taiwan, From GPS, Eos Trans, $A G U, 83$ (47), Fall Meet. Suppl., T61B-1257.

Wu, F.T., R.J. Rau, and D. Salzberg (1997), Taiwan orogen: thin-skinned or lithospheric collision, Tectonophysics, 274, 191-220.

Yang, K.-M., Huang, S.-T., Wu, J.-C., Ting, H.-H.,Mei, W.-W., Lee, M., Hsu, H.-H., and C.-J., Lee (manuscript in preparation, 2007). Terr. Atmos. Oceanic Sci .

Yu, H.S., and Y.W., Chou (2001), Charactheristics and development of the flexural forebulge and basal unconformity of Western Taiwan Foreland Basin. Tectonophysics, 333, 277-291. 
Yu, S.B., H.Y. Chen, and L.C. Kuo (1997), Velocity of GPS stations in the Taiwan area. Tectonophysics, 274, 41-59.

Yue, L.-F., J. Suppe, and J.-H. Hung (2005), Structural geology of a classic thrust belt earthquake: the 1999 Chi-Chi earthquake Taiwan $(\mathrm{Mw}=7.6)$, Journal of Structural Geology, 27, 2058-2083.

Wiltschko, D.V., Hung, J.-H., Fang, P. and Y. Bock (2002), Motion along the EurasianPhilippine Sea Plate boundary in the Longitudinal Valley, Taiwan, from GPS: EOS, v. 83, p. F1277. 


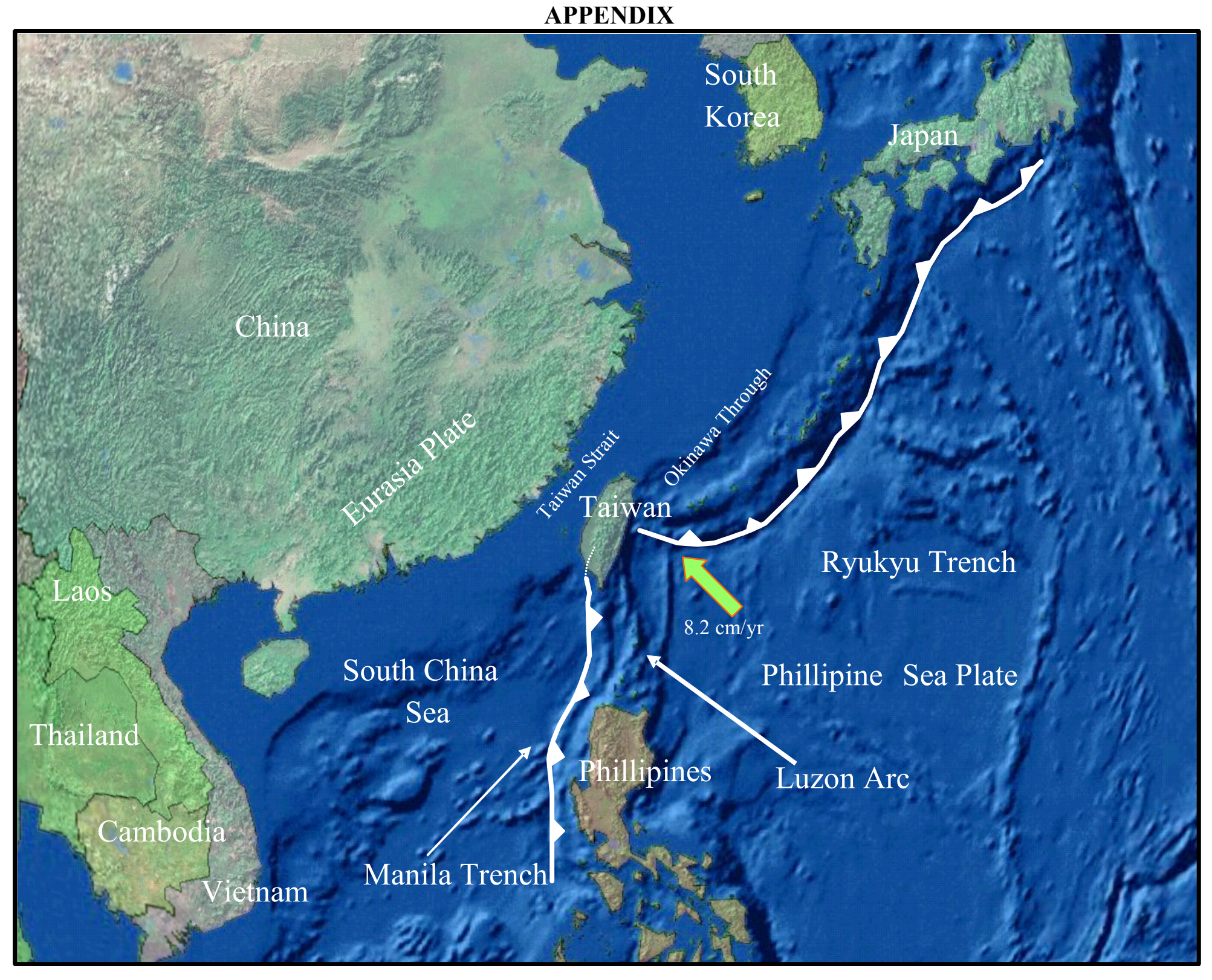

Figure 1. Taiwan Tectonic Context (from ESRI [2007]). 


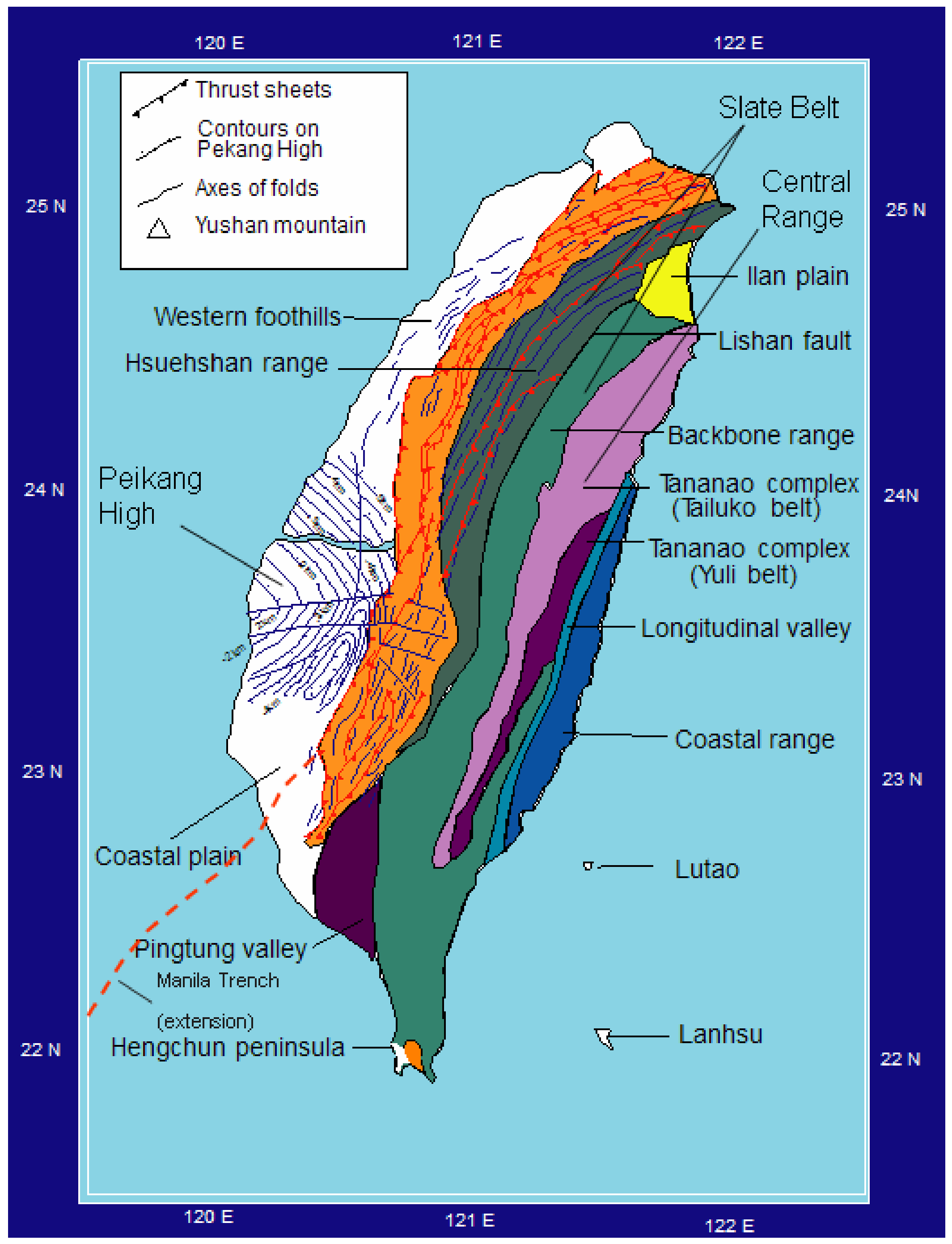

Figure 2. Geologic provinces of Taiwan, (After Sibuet and Hsu, [1997]). 


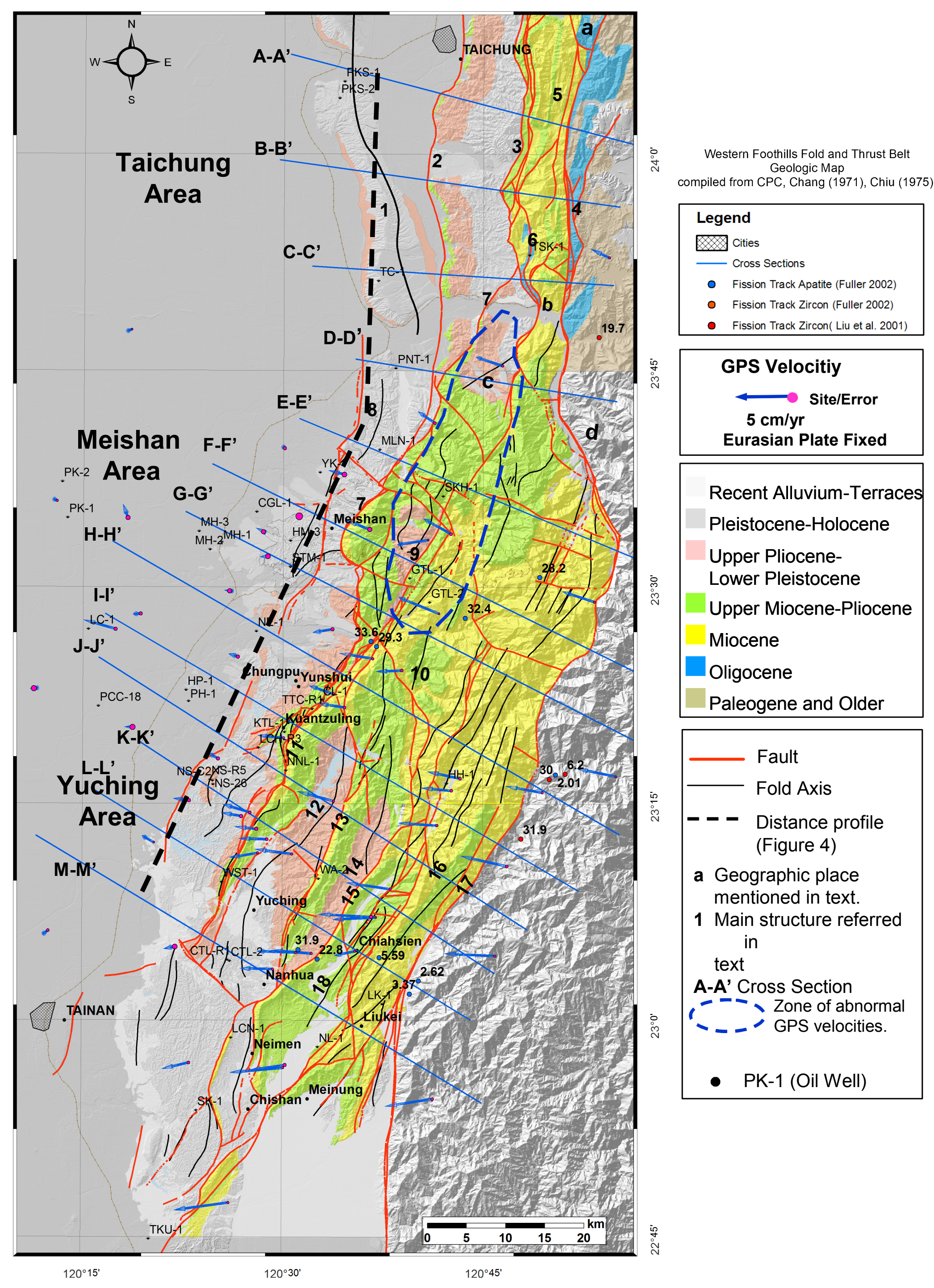

Figure 3. Western Foothills fold and thrust belt geologic map. Compiled from CPC [1986, 1988], Chang, [1971], Chiu [1975]. Numbers on the map are the following: 1: Pakuashan anticline. 2: Chelungpu fault. 3: Schuangtung fault. 4: Tulungwan fault. 5: Tahengpinshan syncline. 6: Tsukeng anticline. 7: Tachienshan fault. 8: Neilin anticline. 9: Luku fault. 10: Tachienshan fault southern segment. 11: Chukou fault. 12: Yuching syncline. 13: Lunhou fault. 14: Yuching syncline. 15: Pingchi fault. 16: Chishan fault. 17: Chaochou fault. 18: Chiahsien syncline. Comments a-d explained in text. 


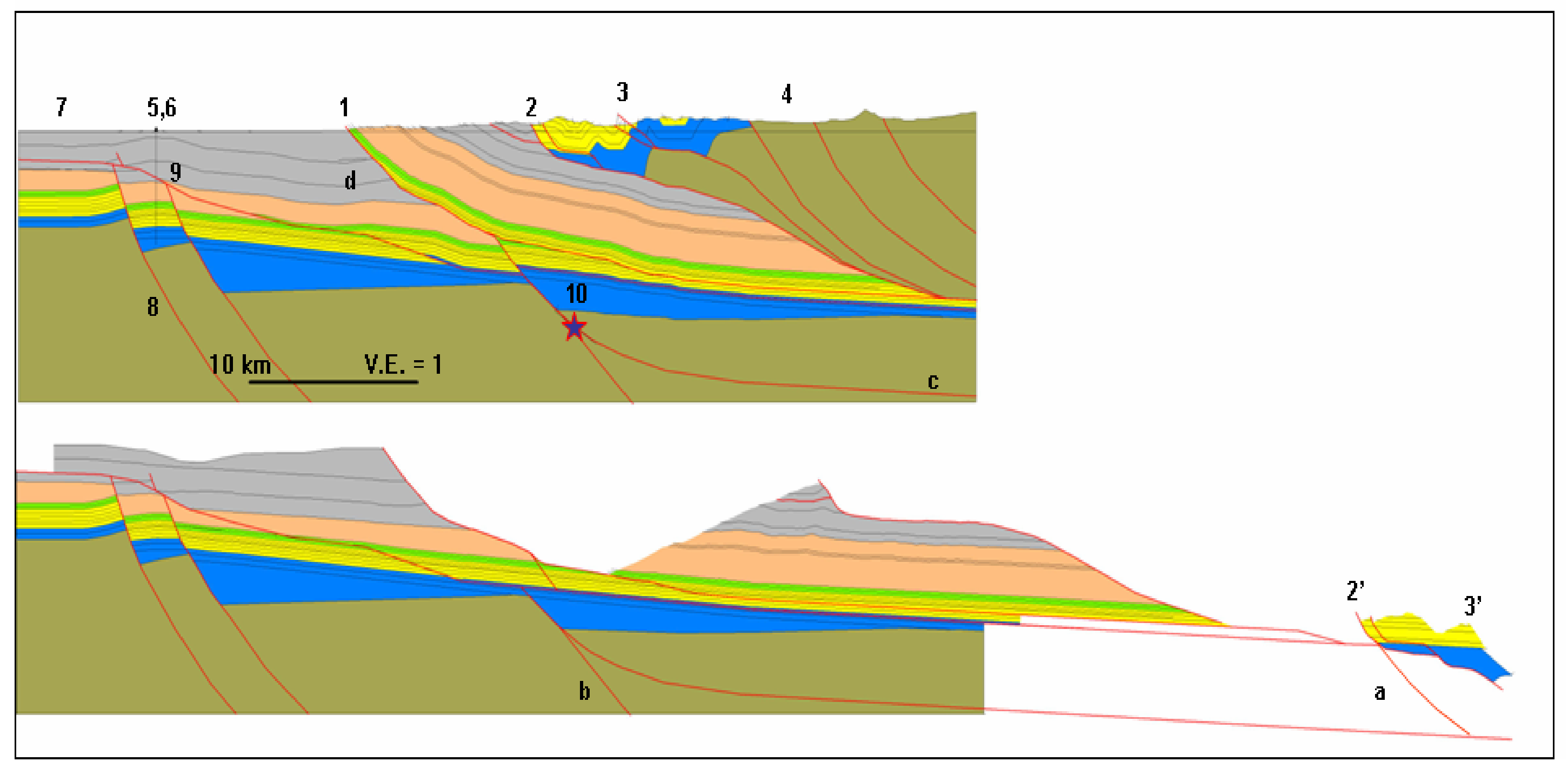

Figure 4. Section A-A. See Figure 3 for location. Numbers on section are the following: 1: Chelungpu fault. 2: Shcuangtung fault. 2': Restored position of point 2. 3: Tulungwan fault. 3': Restored position of point 3. 4: Hsuehshan range. 5: PKS-1 well. 6: Pakuashan anticline. 7: Peikang High. 8: Extensional fault associated with Peikang High. Interpreted from published seismic lines [Chang, 1971], and PKS-1 well data. 9: Changhua fault. 10. Chichi Earthquake hypocenter (star) from Kao et al. [2001]. Comments a to d are the following: a. Normal fault inferred from thickening in Miocene section. A normal fault interpretation preserves the structural style observed toward the south.. See text for details. $\underline{b}$. This pre-existing normal fault is interpreted as being the fault whose shallowest segment was reactivated during the Chi-Chi earthquake. c. This is consistent with focal mechanisms and may be the regional detachment that links with the fault referred to at point $\mathbf{b}$. $\mathrm{d}$. This sub-thrust anticline beneath the Chelungpu fault was placed here based on growth c. This is consistent with focal mechanisms and may be the regional detachment that links with the fault referred to at point $\underline{b}$.. . This sub-thrust anticline beneath 


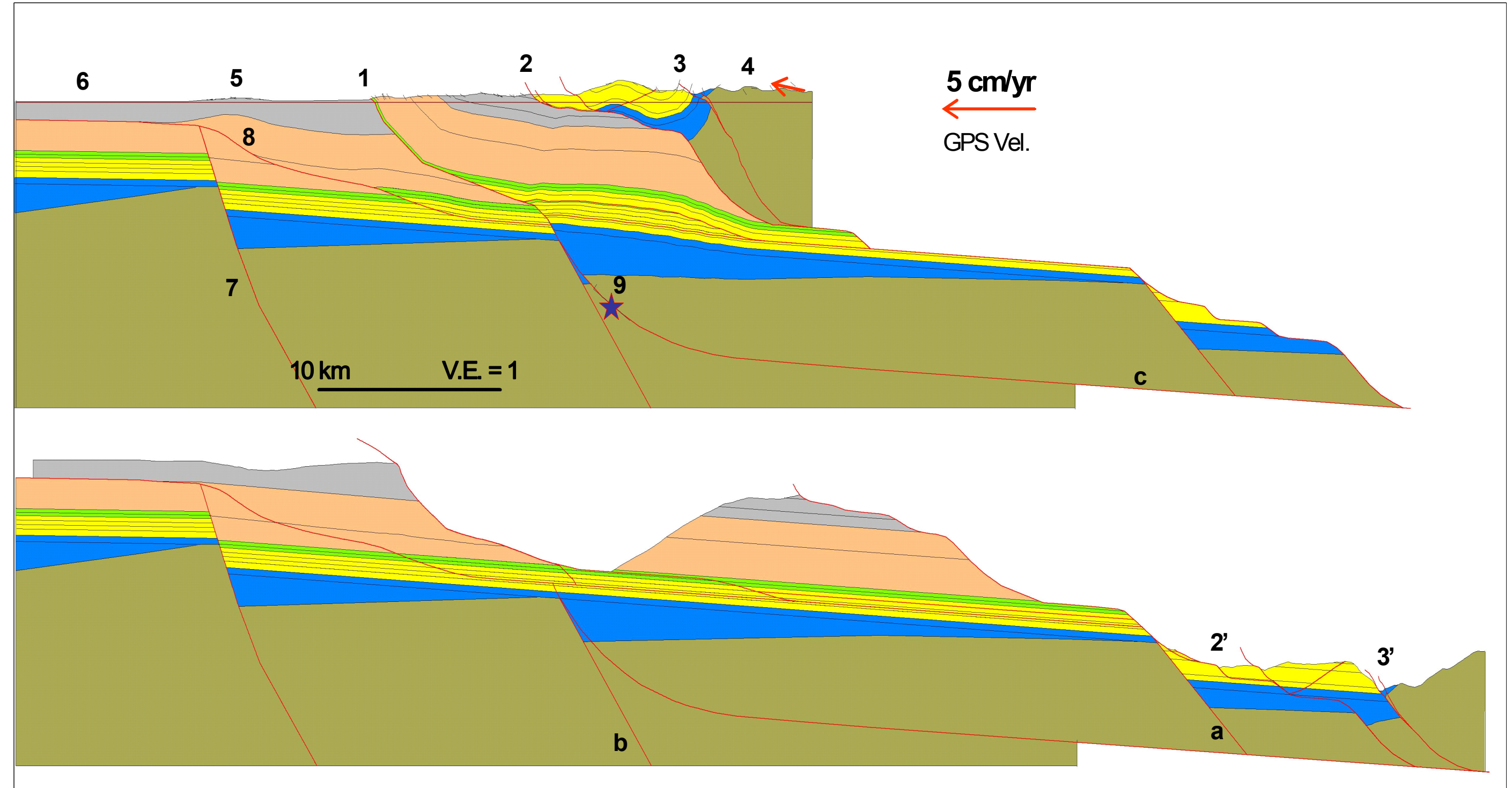

Figure 5. Section B-B'. See Figure 3 for location. Numbers on the section are the following: 1: Chelungpu fault. 2: Schuangtung fault. 2': Restored position of point 2. 3: Tulungwan fault. 3': Restored position of point 3. 4: Hsuehshan range. 5: Pakuashan anticline. 6: Peikang High. 7: Extensional fault associated with Peikang High, see explanation in Figure 10, extrapolated to this section continue the Piekang High toward the south. 8: Changhua thrust. 9: Chichi Earthquake hypocenter (star) from Kao et al. [2001]. Comments a to c are the following: a: Normal fault inferred from thickening in Miocene section. See text for details. $\underline{b}$ : This pre-existing normal fault is interpreted as being the fault whose shallowest segment will be reactivated during the Chi-Chi earthquake. $\underline{c}$. This detachment is consistent with focal mechanisms and may be the regional detachment that link with the fault explained in point $\underline{b}$. See text for details. 


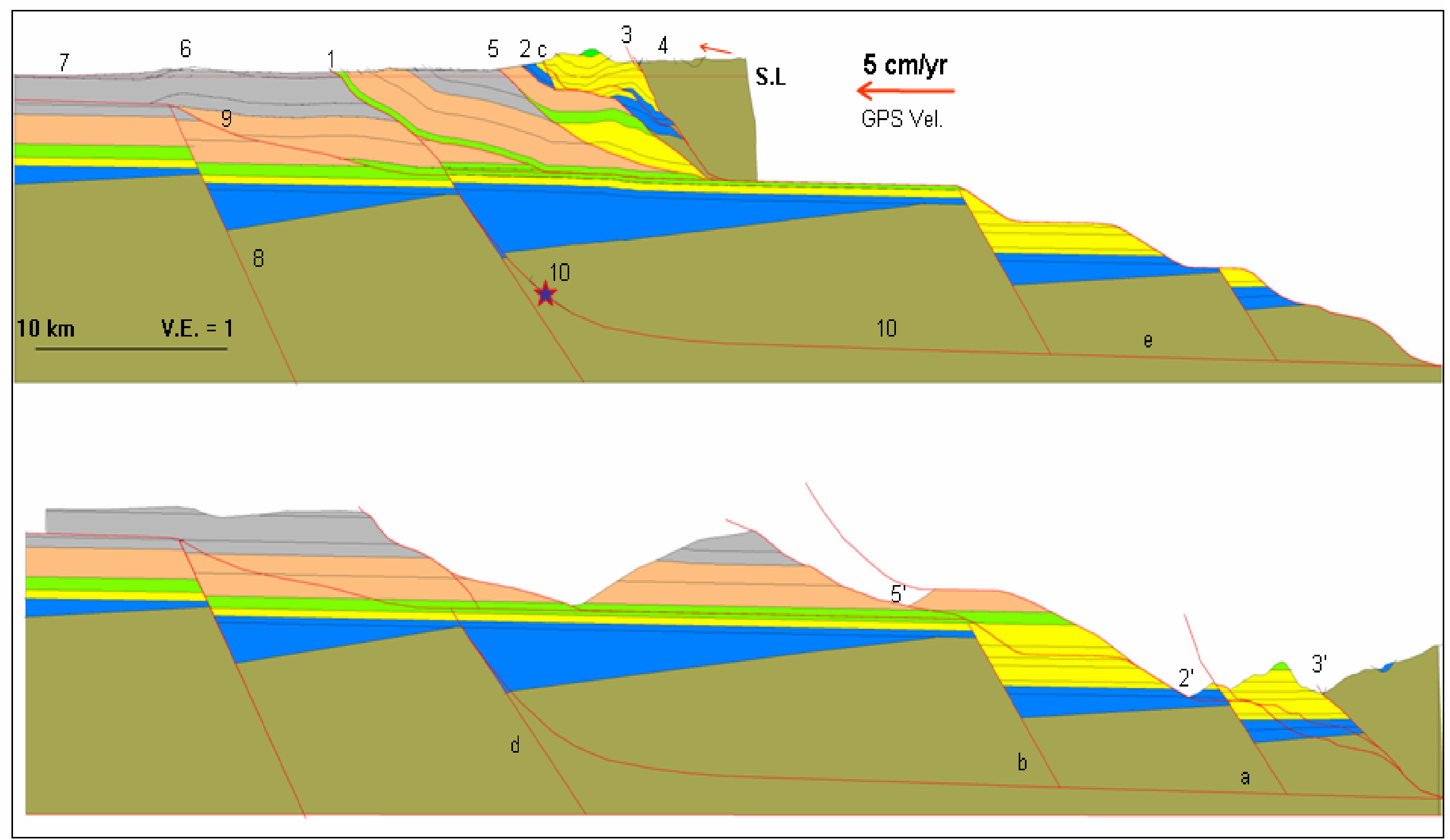

Figure 6. Section C-C'. See Figure 3 for location. Numbers on section are the following: 1: Chelungpu fault. 2: Schuangtung fault. 2': Restored position of point 2. 3: Tulungwan fault. 3': Restored position of point 3. 4: Hsueshan range. 5. Tachienshan fault. 5' Restored position of point 5. 6: Pakuashan anticline. 7: Peikang High. 8: Extensional fault associated with Peikang High, see explanation in Figure 10, extrapolated to this section continue the Piekang High toward the south. 9: Changhua thrust. 10: Chichi Earthquake hypocenter (star) from Kao et al. [2001]. Comments a to e are the following: a and b: Normal fault inferred from section continue the Piekang High toward the south. 9: Changhua thrust. 10: Chichi Earthquake hypocenter (star) from Kao et al. [2001]. Comments a to e are the following: a and b: Normal fault inferred from 


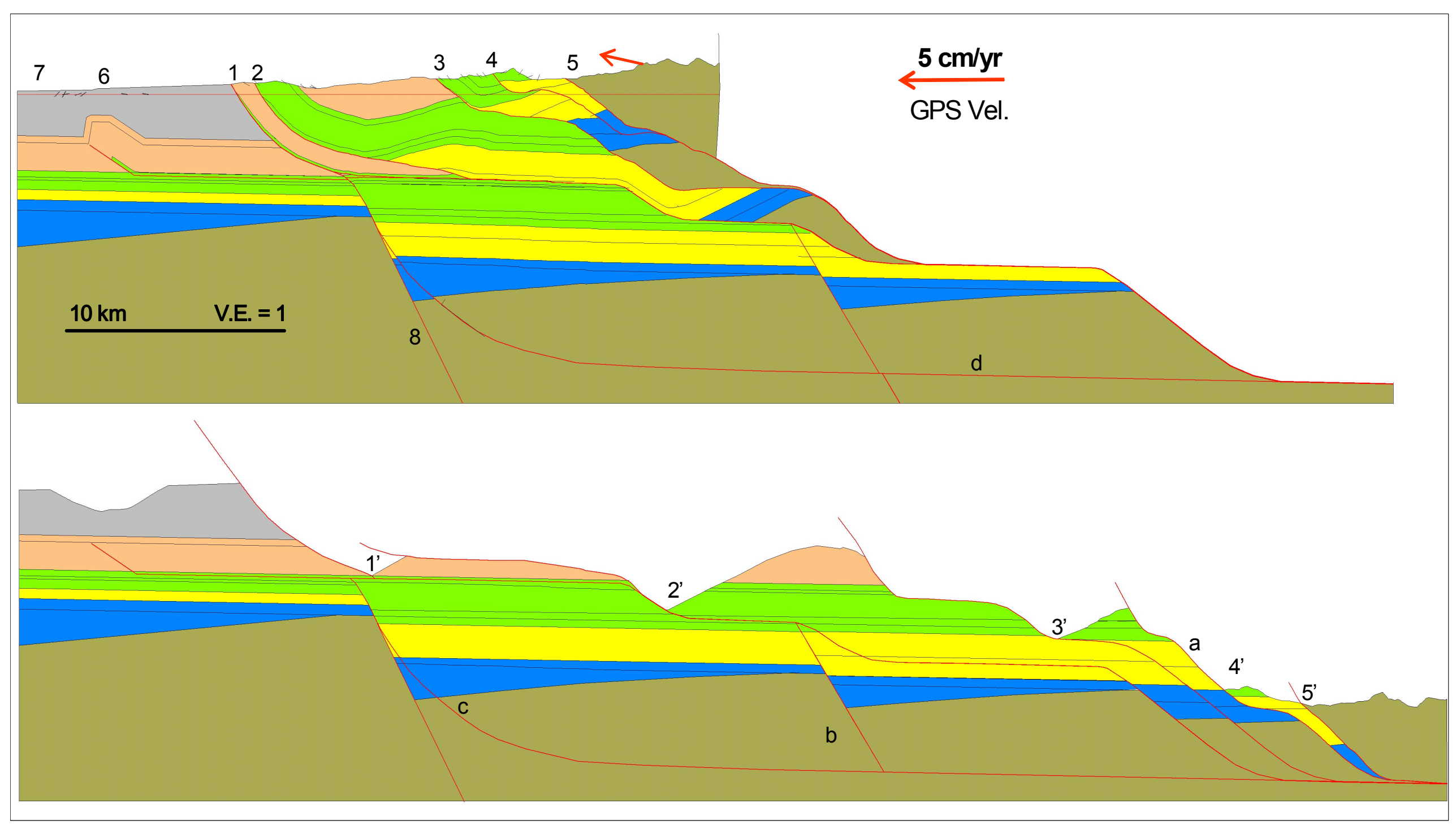

Figure 7. Section D-D'. See Figure 4 for location. Numbers on section are the following: 1: Chelungpu fault. 1': Restored position of point 1. 2: Tachienshan fault. 2': Restored position of point 2. 3: FenghuachanLuku fault. 3': Restored position of point 3. 4: Schuangtung fault. 4': Restored position of point 4. 5: Tulungwan fault. 5' Restored position of point 5. 6: Meilin anticline. 7: Peikang High. 8: Extensional fault associated with Peikang High, interpreted here from the change in thicknesses between the Peikang High Cenozoic rocks and the thrust belt Cenozoic rocks. Comments a to $\underline{\mathrm{d}}$ are the following: $\underline{\text { a }}$. Normal fault inferred from thickening in Miocene section. In this particular case this block restored to a deeper position than in neighbor with the same amount of shortening. It could be restored to a shallower position by making Cestring the footwall flat beneath point c' longer, without making major modifications to the cross section. $b$. We choose to interpret a normal fault here to preserve the structural style interpreted in sections to the north. $c$. See point $\mathbf{b}$ in Figure 4 for explanation. $\underline{d}$. See point $\mathbf{c}$ in figure 4 for details. 


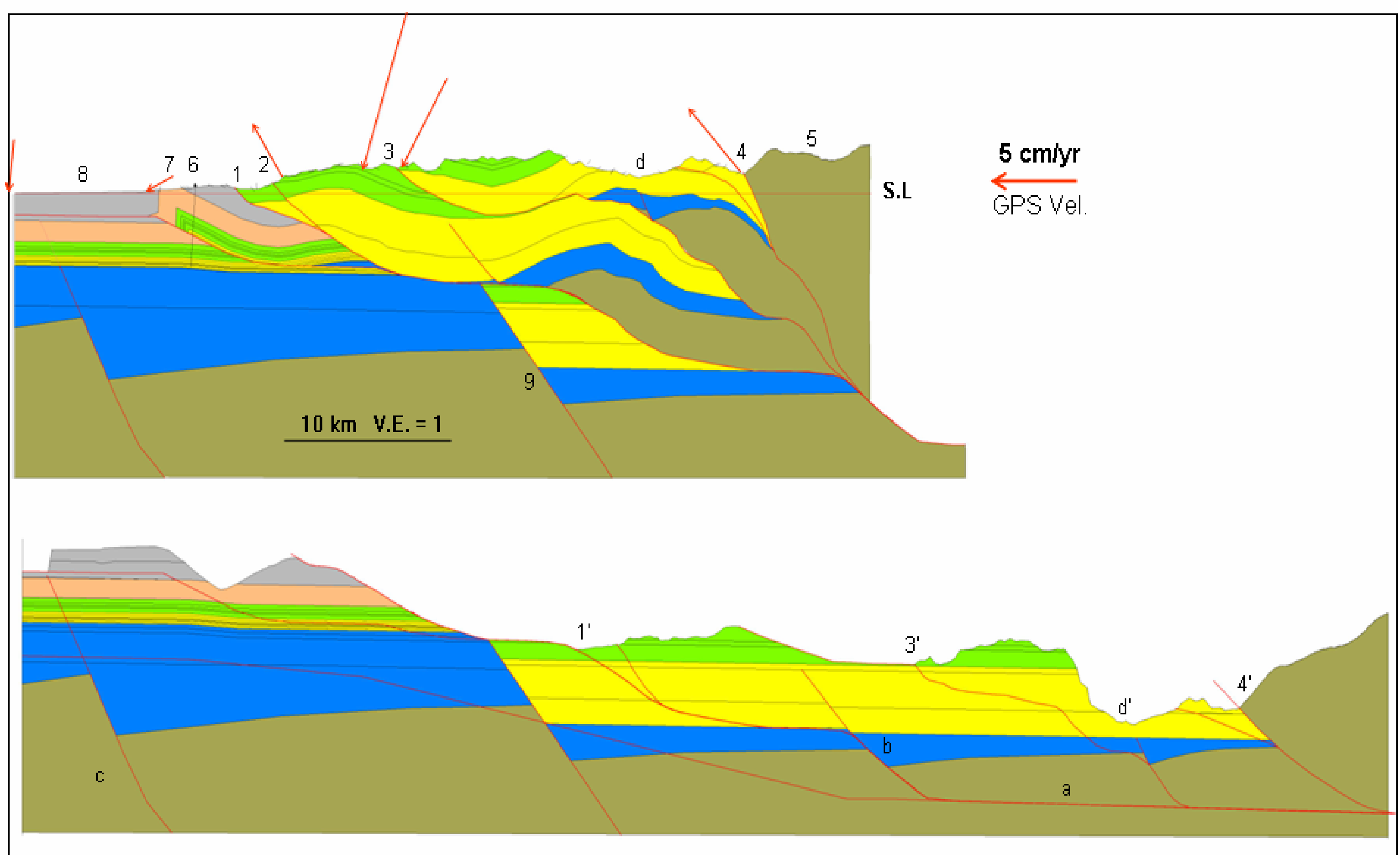

Figure 8. Section E-E'. See Figure 3 for location. Numbers on section are the following: 1: Chelungpu fault. 1': Restored position of point 1. 2: Tachienshan fault. 2': Restored position of point 2. 3: FenghuachanLuku fault. 3': Restored position of point 3. 4: Tulungwan fault. 4': Restored position of point 4. 5: Hsueshan range. 6: MLN-1 well. 7: Neilin anticline. 8: Peikang High. 9: Same as 8 in Figure 7. Comments a to c are the following: $\underline{a}$. Normal fault inferred from thickening in Miocene section. $\underline{b}$ and $\underline{c}$ interpreted to be consistent with the structural style. $\underline{\mathrm{d}}$. This point shows the restored depth of the lower Miocene sediments and implies the thickening of Miocene sedimentary section. 


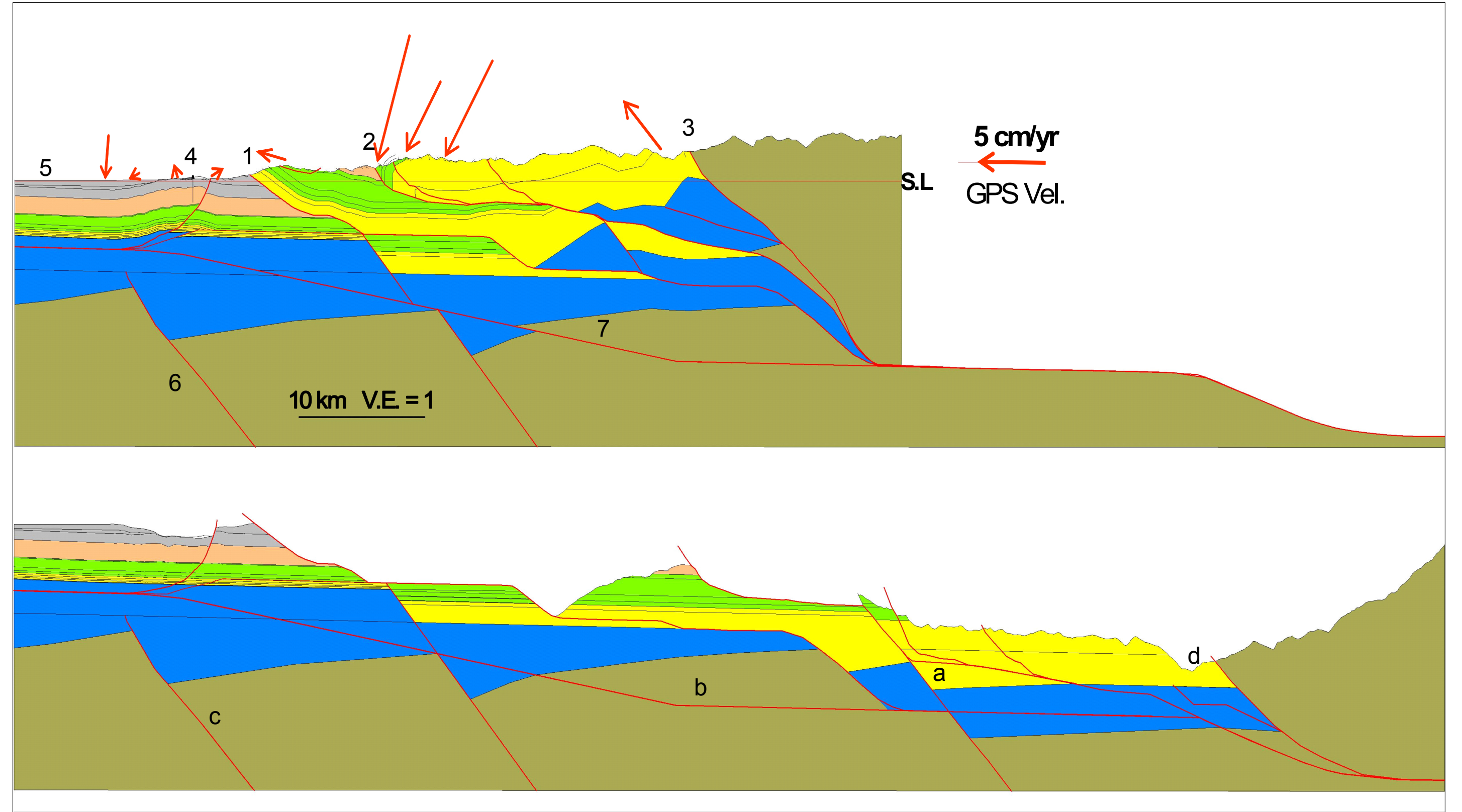

Figure 9. Section F-F'. See Figure 3 for location. Numbers on section are the following: 1: Tachienshan fault. 2: Fenghuachan-Luku fault. 3: Tulungwan fault. 4: R-1 well. 5: Peikang High. 6: Same as 8 in Figure 7.7: Sub-Yuching fault. Comments a to $\underline{d}$ are the following: a. Normal fault inferred from thickening in Miocene section. $\underline{b}$. Northern extension of the Sub-Yuching thrust. Detachment depth is consistent with focal mechanisms [Carena et al., 2002]. c. A normal fault interpreted to preserve the structural style interpreted in sections to the north. $\mathrm{d}$.See point $\mathrm{d}$ Figure 8 . 


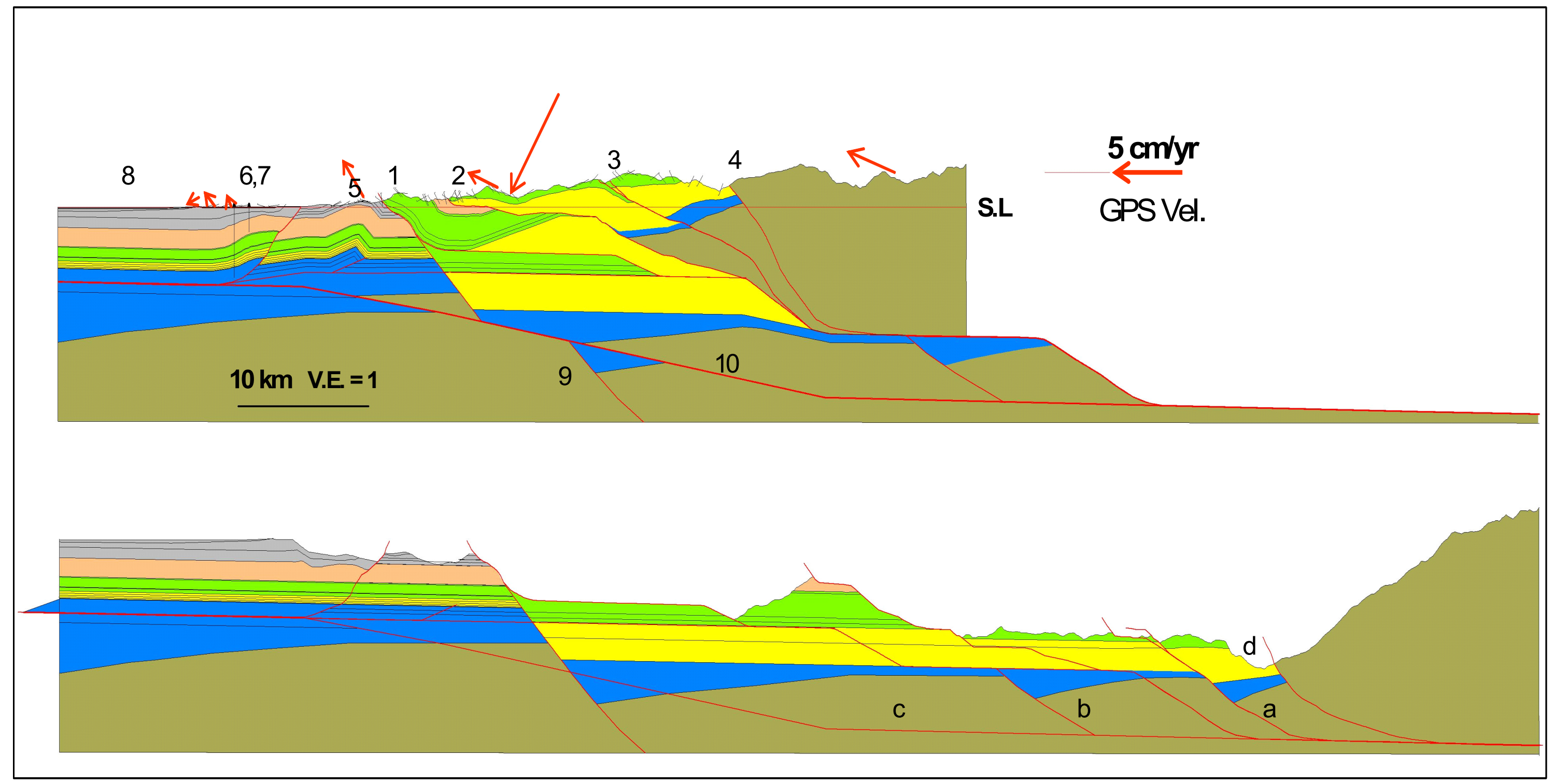

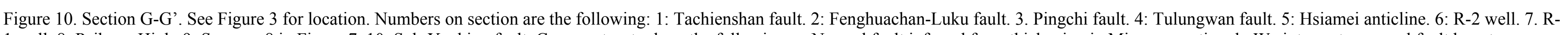
1 well. 8: Peikang High. 9: Same as 8 in Figure 7. 10: Sub-Yuching fault. Comments $\underline{a}$ to $\underline{d}$ are the following: a. Normal fault inferred from thickening in Miocene section. $\underline{b}$. We interpret a normal fault here to preserve the structural style interpreted in sections to the north. $\underline{\mathrm{c}}$. The detachment for the Sub-Yuching fault is consistent with focal mechanisms [Carena et al., 2002]. $\underline{\mathrm{d}}$. Same as point $\underline{\mathrm{d}}$ Figure 8 . 


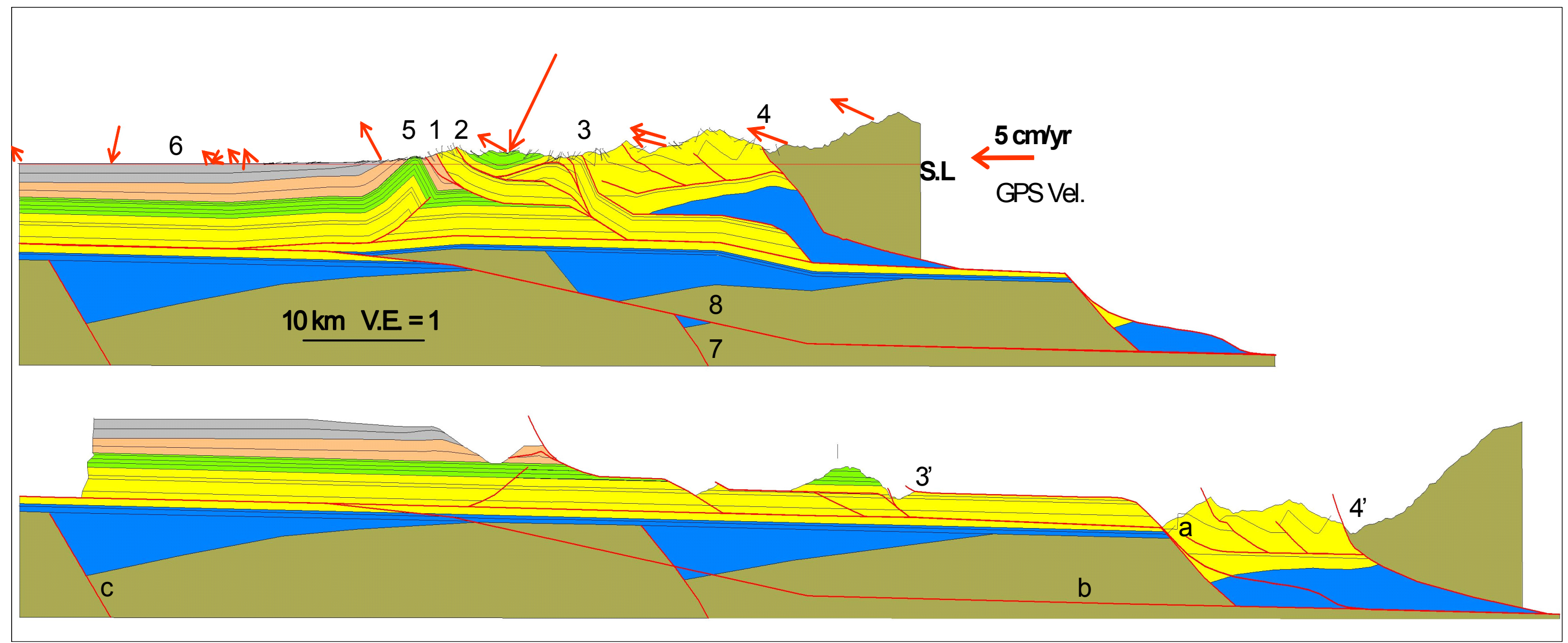

Figure 11. Section H-H'. See Figure 3 for location. Numbers on section are the following: 1: Chukou fault. 2: Lunhou fault. 3. Tachienshan-Pingchi fault. 4: Tulungwan fault. 5: Kuantzuling-Nanliao anticline. 6: Peikang High. 7: Extensional fault associated with Peikang High, interpreted here from the change on thicknesses between the Peikang high Cenozoic rocks and the thrust belt Cenozoic rocks. 8: Sub-Yuching fault. Comments a to $\underline{\mathrm{c}}$, see Figure 10 for explanation. 


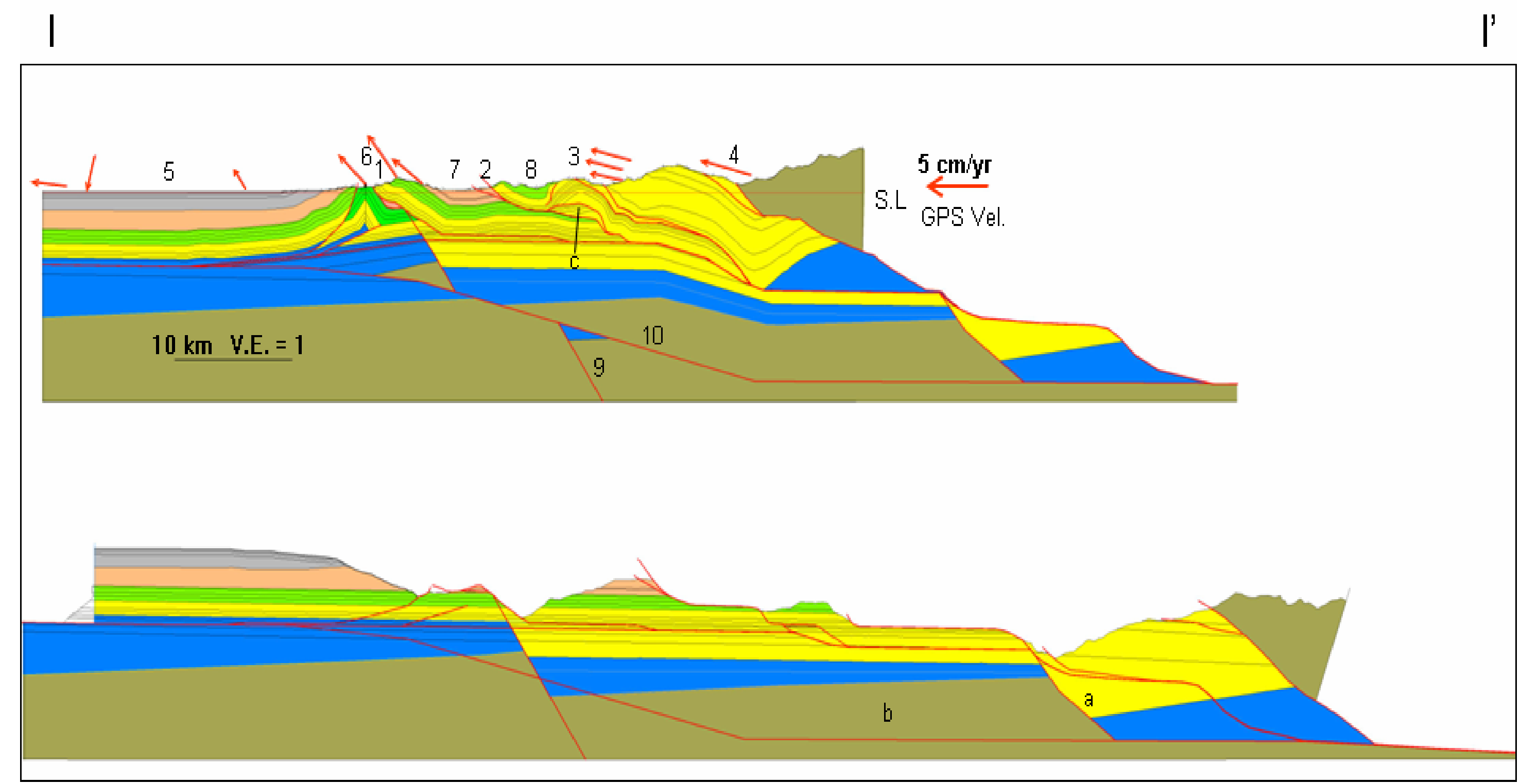

Figure 12. Section I-I'. See Figure 3 for location. Numbers on section are the following: 1: Chukou fault. 2: Lunhou fault. 3. Tachienshan-Pingchi fault. 4: Tulungwan fault. 5: Peikang High. 6: KTL-3 well. 7. Yuching syncline. 8. Tingpinglin Syncline. 9: Same as 8 in Figure 7. 10: Sub-Yuching fault. Comments a and $\underline{b}$, see points a and $\underline{\mathbf{c}}$ in Figure 10 for explanation. 


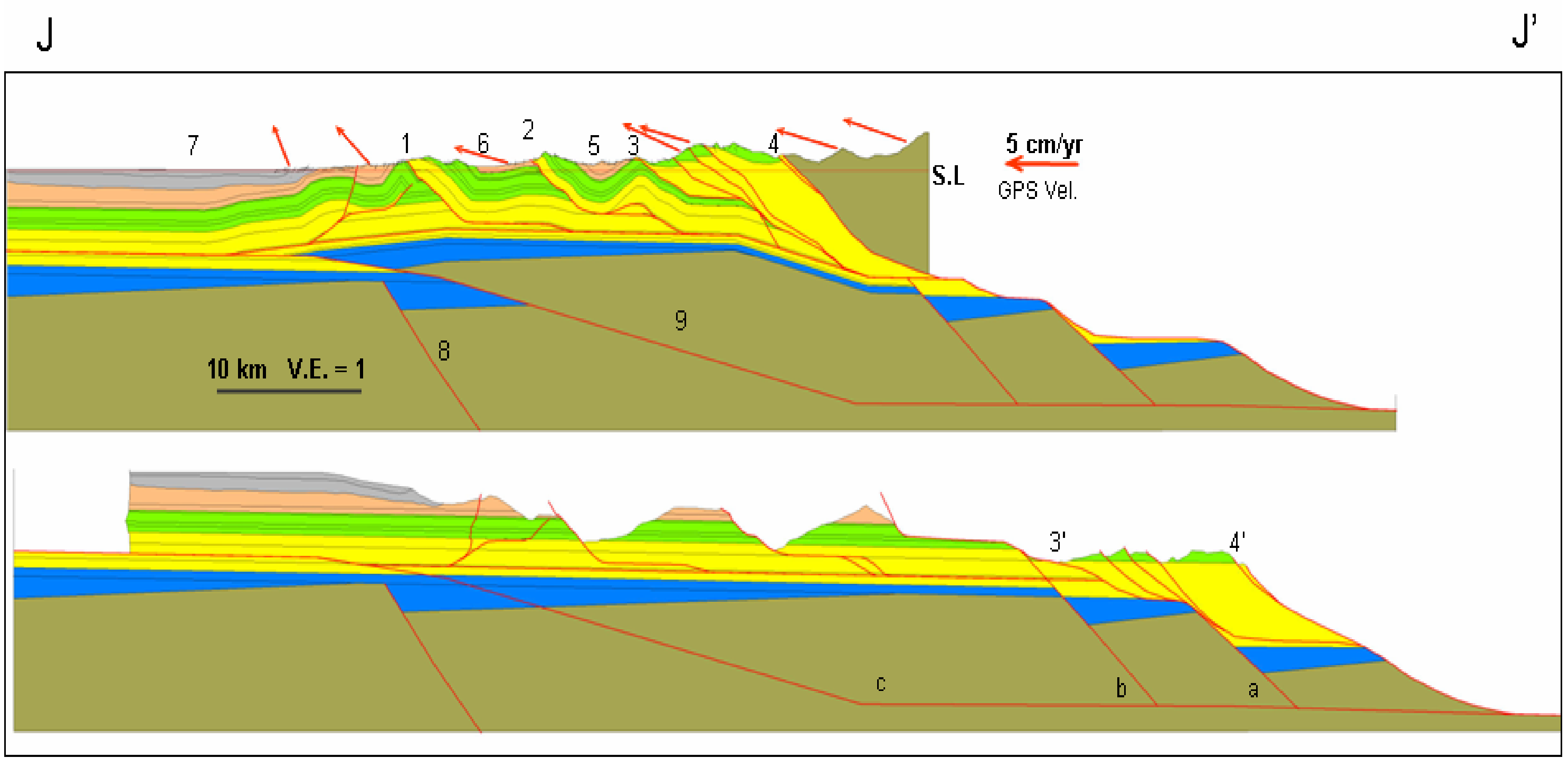

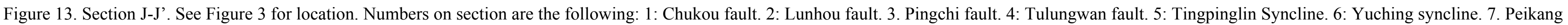
High. 8: Same as 8 in Figure 7. 9: Sub-Yuching fault. Comments a to $\mathbf{c}$ are, see point a to $\mathrm{c}$ in Figure 10 for explanation. 
$\mathrm{K}$

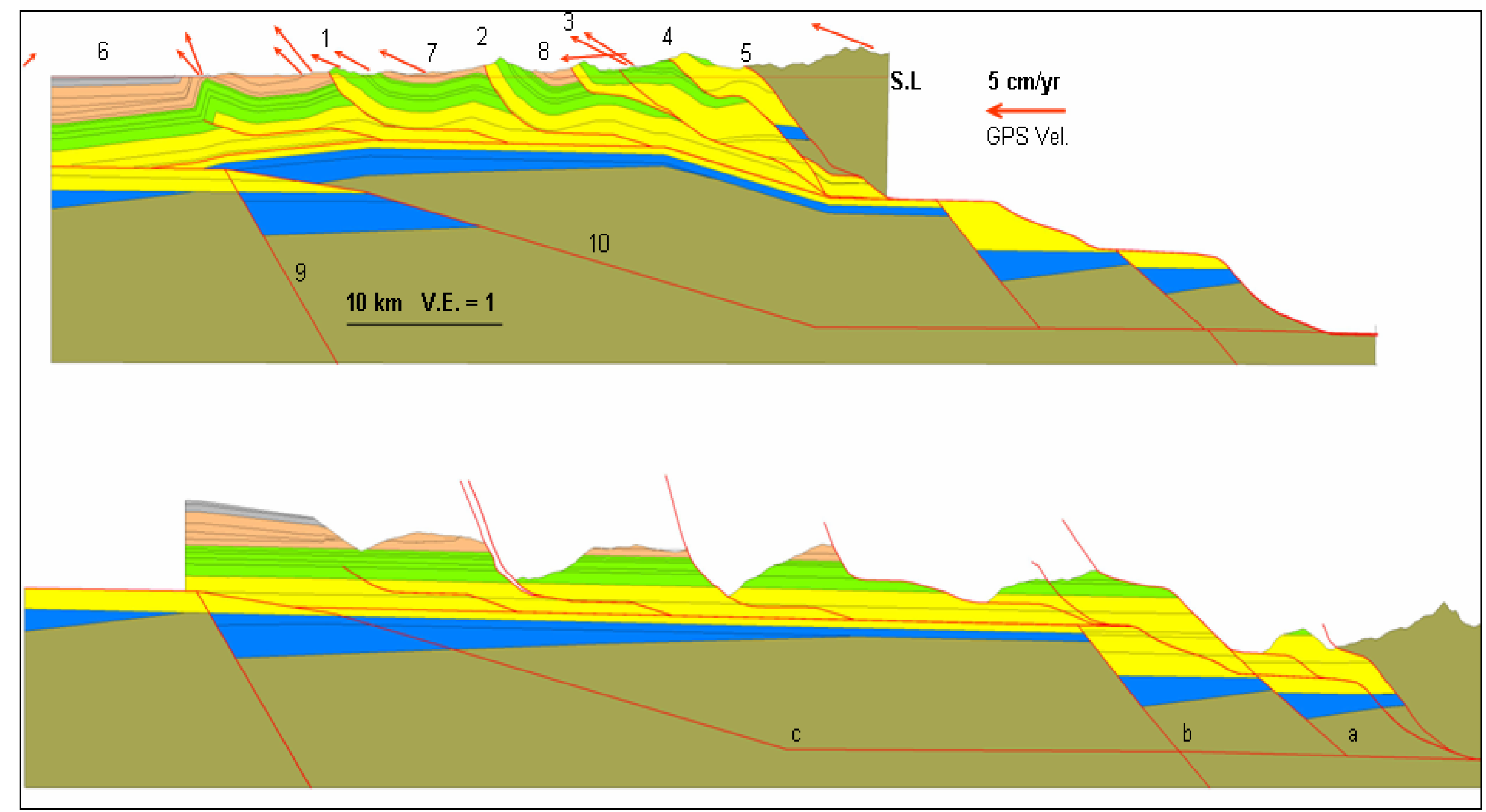

Figure 14. Section K-K'. See Figure 3 for location. Numbers on section are the following: 1: Chukou fault. 2: Lunhou fault. 3. Pingchi fault. 4: Chishan fault. 5: Tulungwan-Chaochou fault. 6: Peikang High. 7. Yuching Syncline. 8: Tingpinglin syncline. 9: Same as 8 in Figure 7. 10: Sub-Yuching fault. Comments $\underline{a}$ to $\underline{\mathrm{c}}$ are, see points $\underline{a}$ to $\underline{\underline{c}}$ in Figure 10 for explanation. 


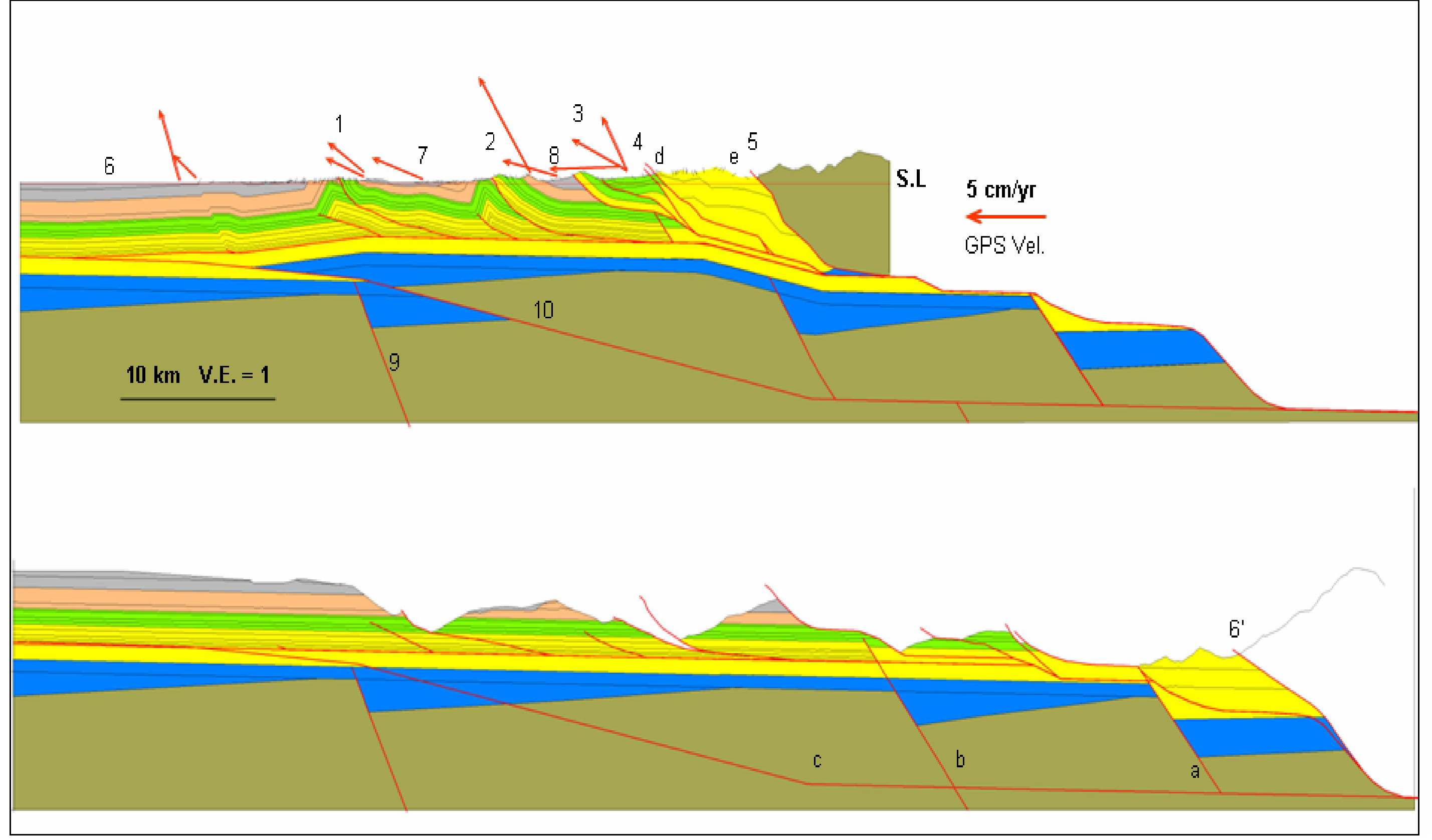

Figure 15. Section L-L'. See Figure 3 for location. Numbers on section are the following: 1: Chukou fault. 2: Lunhou fault. 3. Pingchi fault. 4: Chishan fault. 5: Tulungwan-Chaochou fault. 6: Peikang High. 7. Yuching Syncline. 8: Tingpinglin syncline. 9: Extensional fault associated with Peikang High. 10: Sub-Yuching fault. Comments $\underline{a}$ to $\underline{\underline{e}}$ are the following: Comments $\underline{a}$ to $\underline{\underline{c}}$ are, see point $\underline{a}$ to $\underline{\mathrm{c}}$ in Figure 10 for explanation. ‥ Partially reset AFT sample (5.5 Ma), from Fuller [2002]. e. Partially reset AFT sample (3.3 Ma), from Fuller [2002]. See text for details. 


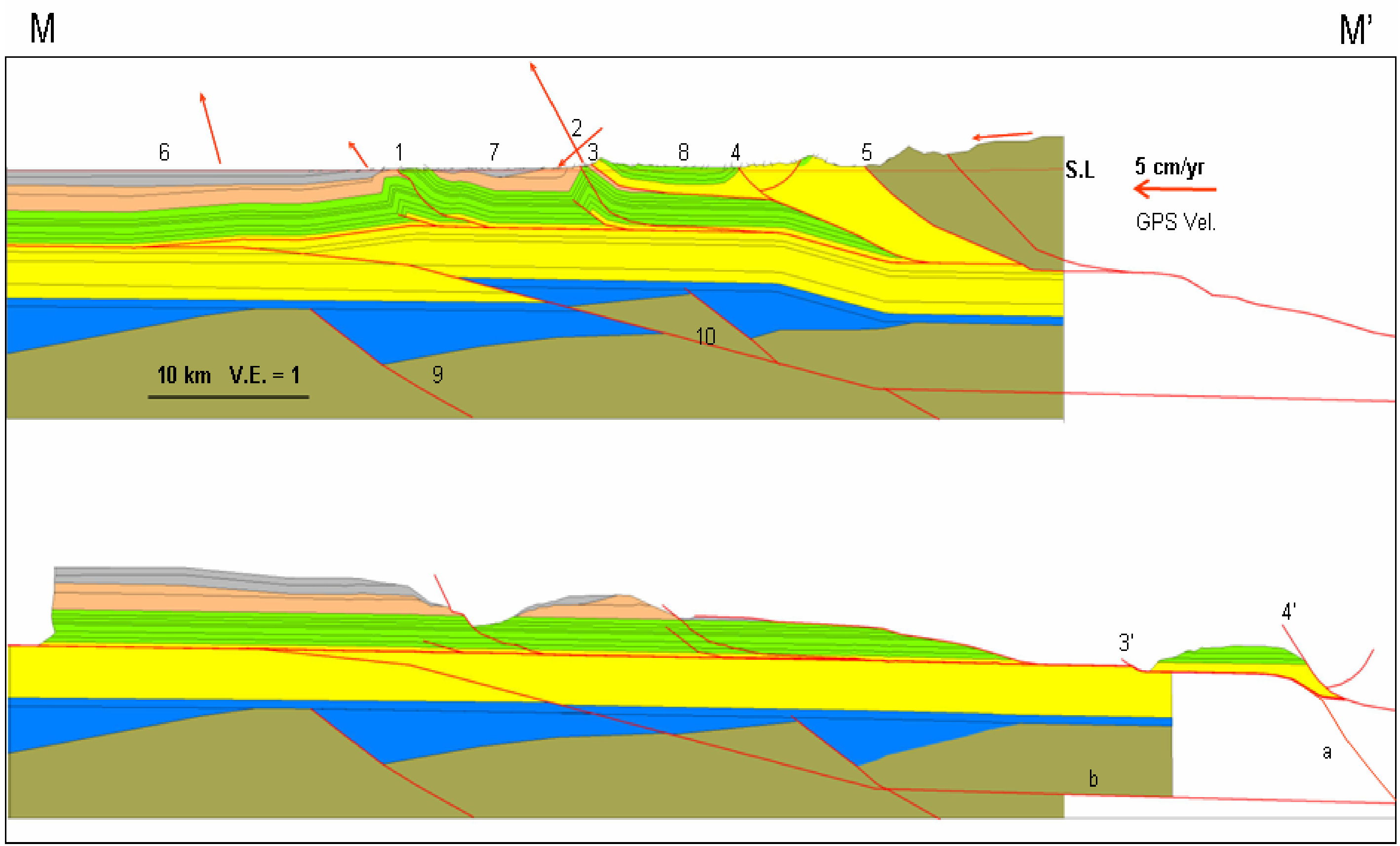

Figure 16. Section M-M'. See Figure 3 for location. Numbers on section are the following: 1: Chukou fault. 2: Lunhou fault. 3. Pingchi fault. 4: Chishan fault. 5: Tulungwan-Chaochou fault. 6: Peikang High. 7. Yuching Syncline. 8: Chiahsien syncline. 9: Extensional fault associated with Peikang High. 10: Sub-Yuching fault. Comments a and $\underline{b}$, see point a and b in Figure 10 for explanation. 


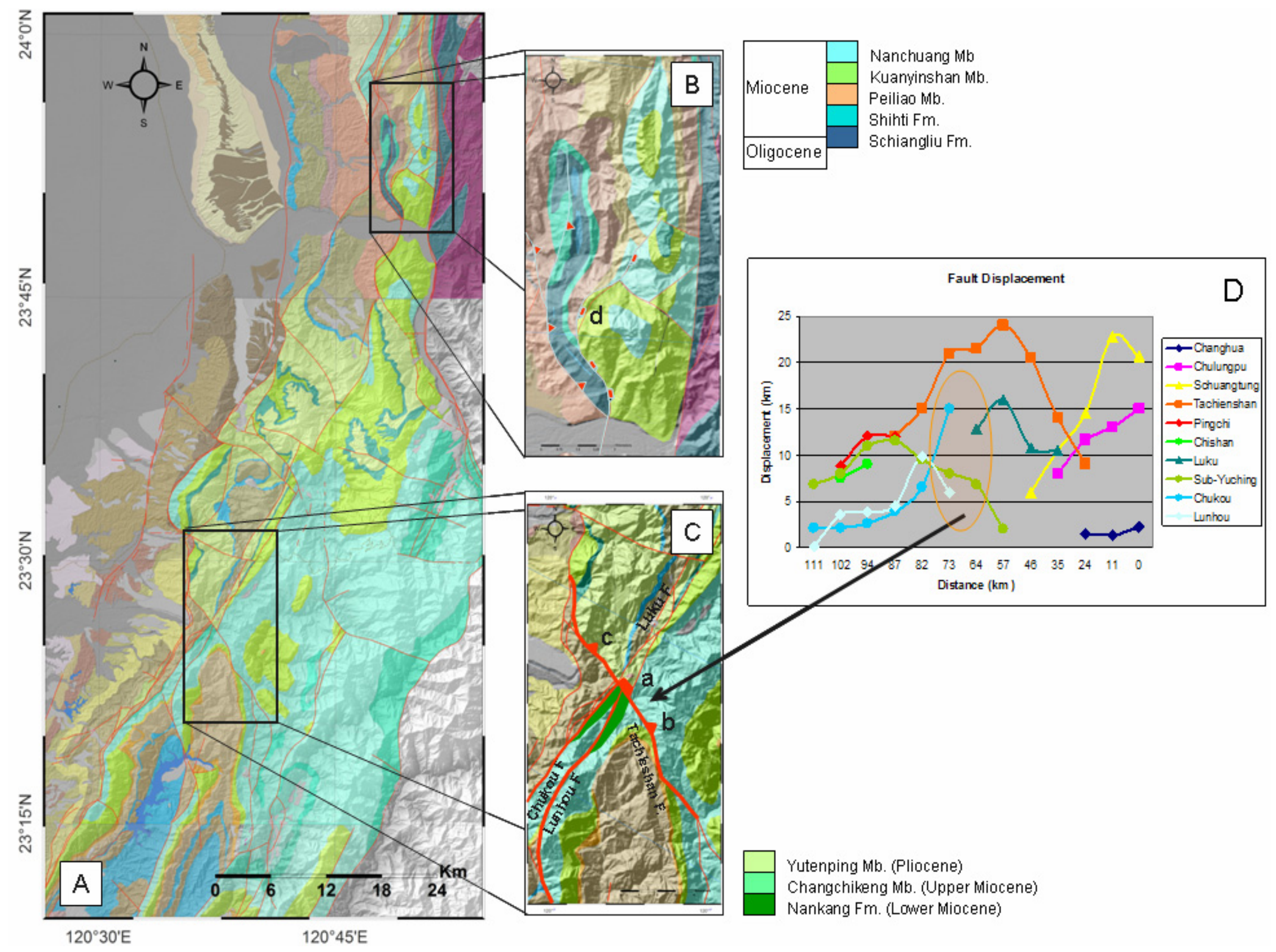

Figure 17 Examples of normal and inverted fault in the Western Foothills. A. Location of B and C. B. Example of a transported normal fault on the Schuangtung fault. C. Example of the out of sequence relationship on the Tachienshan fault truncating the Chukou and Lunhou faults. Letters in $\mathrm{C}$ show an inverted fault example along the Tachienshan fault. Points $\mathrm{b}$ and $\mathrm{c}$ show a reverse fault relationship across the Tachienshan fault. Point a shows a normal fault relationship across the Tachienshan fault. See text for details. D. Detail of out-of-sequence relationship. See figure 18 for details. 


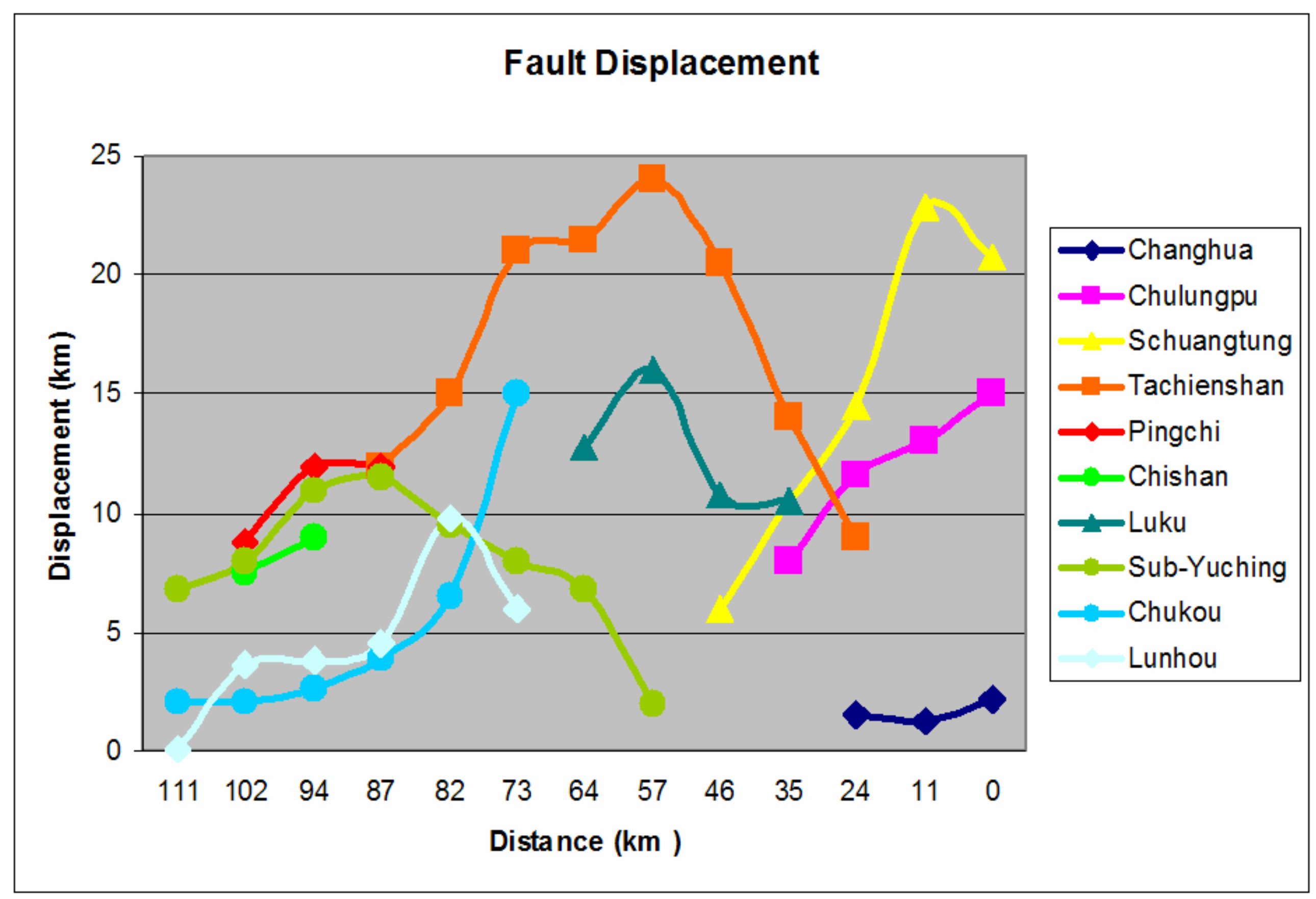

Figure 18. Fault displacement vs. distance along strike. For location of distance profile see Figure 3 (dashed line). See text for details.. 


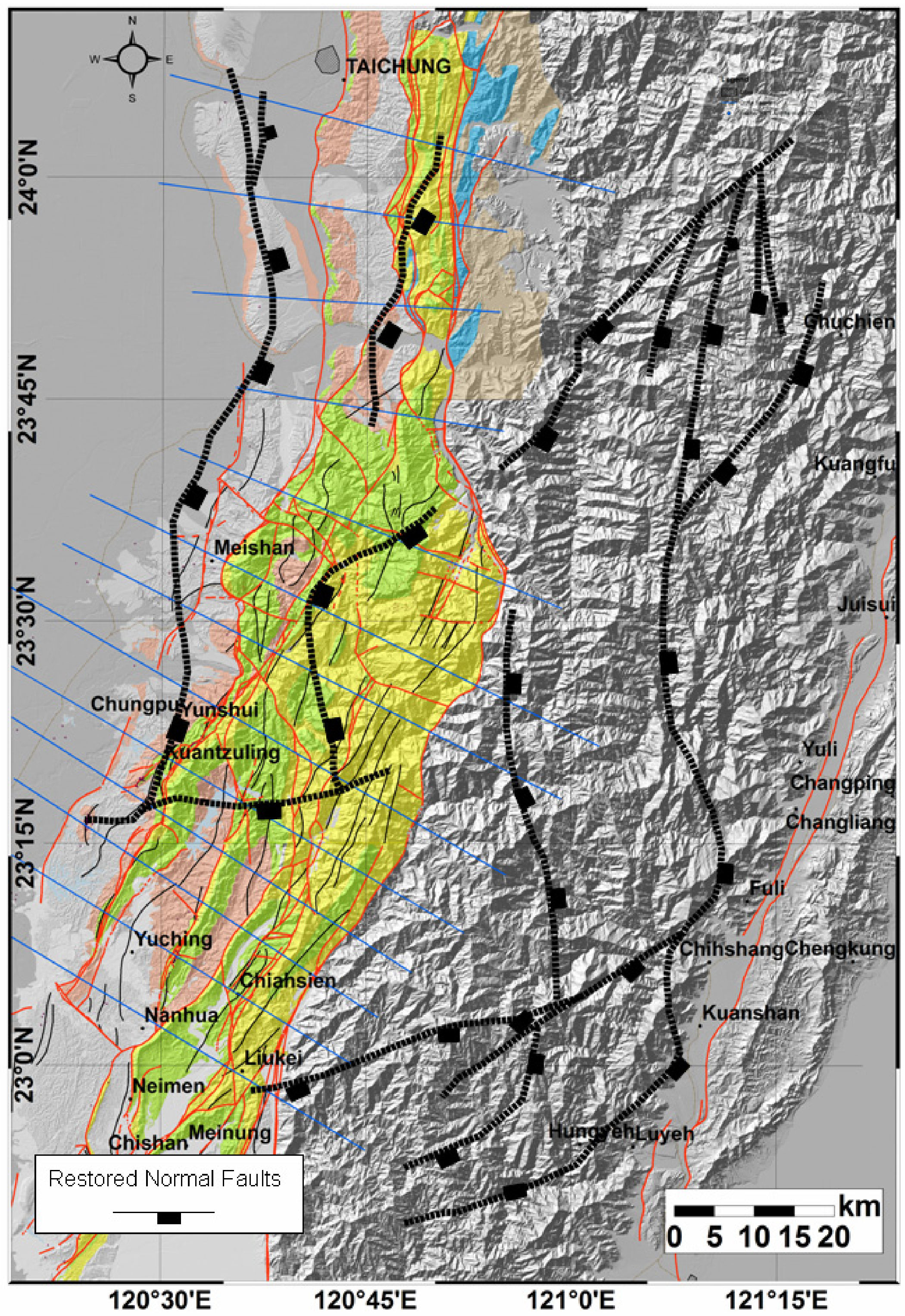

Figure 19. Geologic map of central and southern Taiwan showing the restored position of identified normal faults, estimated from balanced cross sections. 


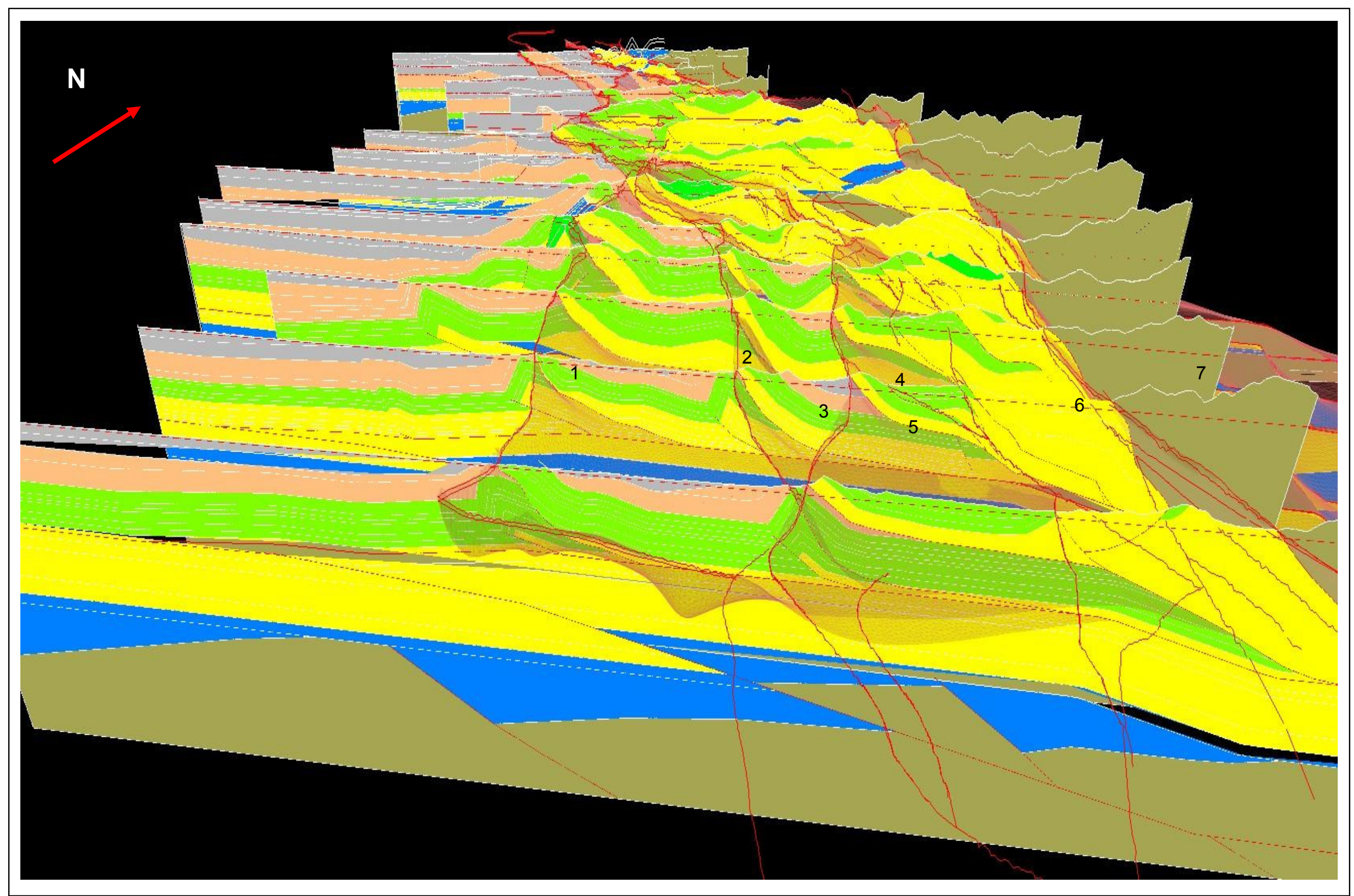

Figure 20. 3D structural model looking from the south. Numbers on figure are the following: 1: Chukou fault. 2: Yuching syncline. 3: Lunhou fault. 4: Tingpinglin syncline. 5: Pingchi fault. 6: Chishan fault. 7: Chaochou fault. 


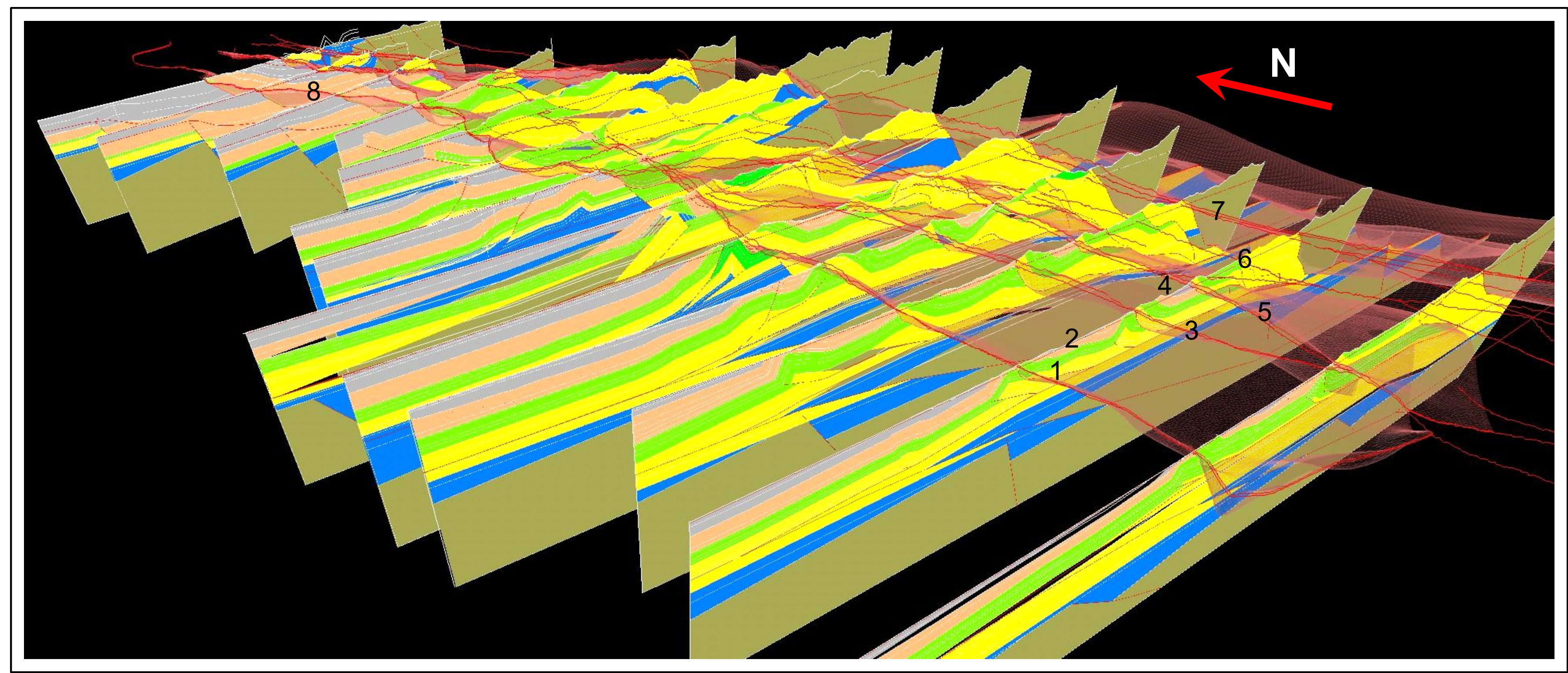

Figure 21. 3D structural model looking from the south-west. Numbers on figure are the following: 1: Chukou fault. 2: Yuching syncline. 3: Lunhou fault. 4: Tingpinglin syncline. 5: Pingchi fault. 6: Chishan fault. 7: Chaochou fault. 8: Chelungpu fault. 


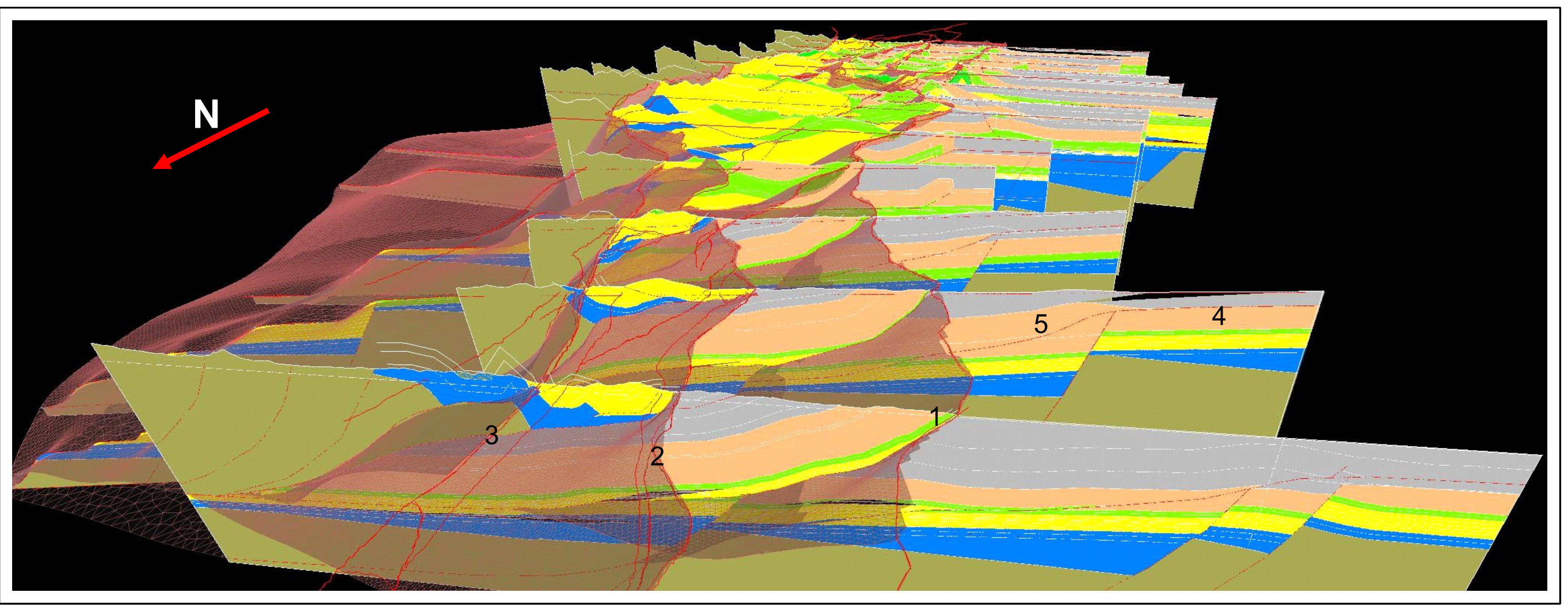

Figure 22. 3D structural model looking from the north. Numbers on figure are the following: 1: Chelungpu fault. 2: Schuangtung fault. 3: Tulungwan fault. 4: Peikang High. 5: Changhua fault. 


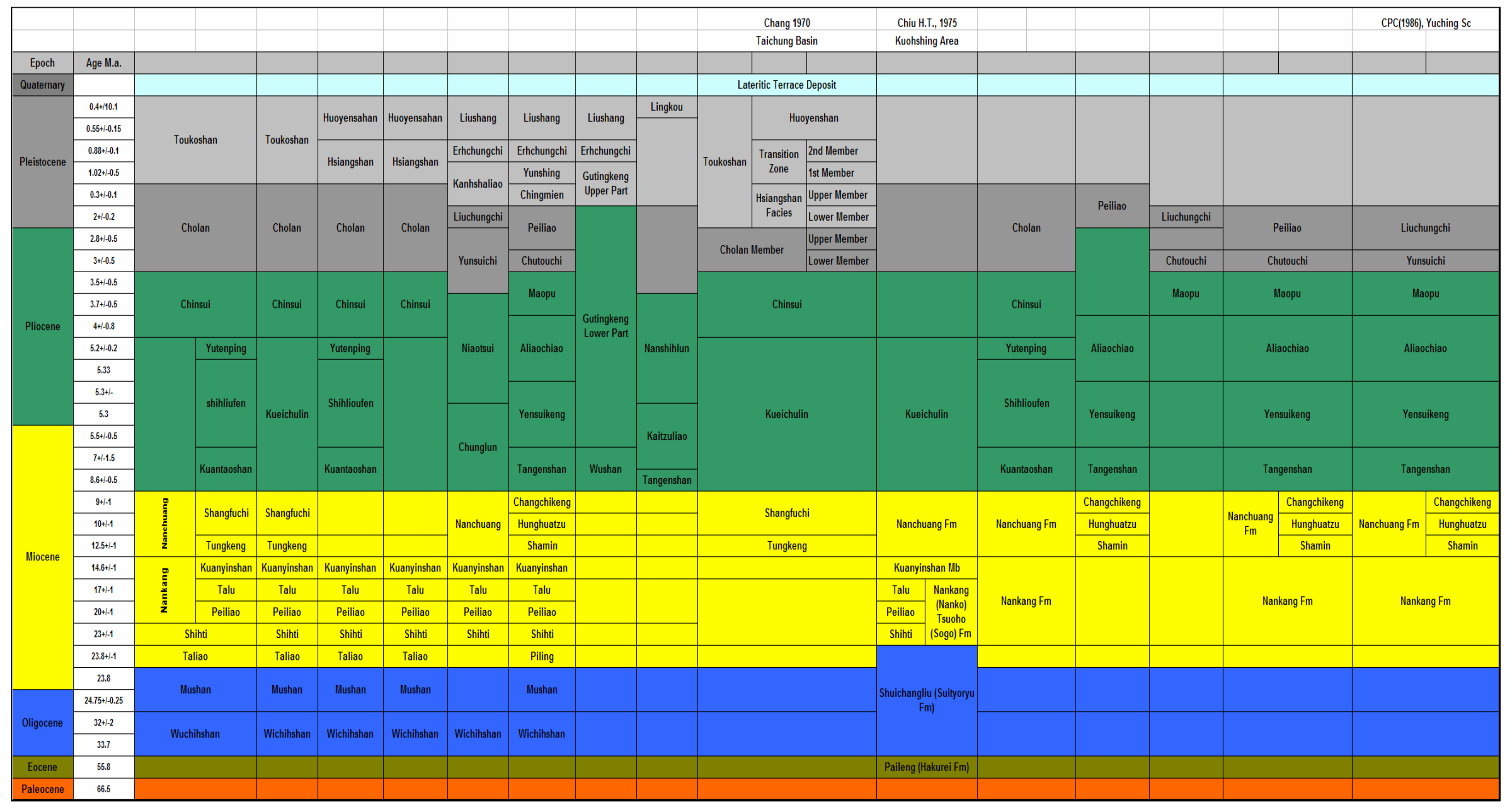

Figure 23. Compiled stratigraphic nomenclature for the central and southern Western Foothills of Taiwan. After Tensi et al. [2006] 


\title{
VITA
}

\author{
Name: \\ Fernando Antonio Rodriguez-Roa \\ Address: \\ Conoco-Phillips, Midland, Tx \\ E-mail Address: ferchorodriguez@gmail.com \\ Education: $\quad$ B.S., Geology, Universidad Nacional de Colombia, Bogota, 2001 \\ M.S., Geology, Texas A\&M University, 2007
}

